\title{
A Functional Approach to Borrowing Limitations Periods for Federal Statutes
}

\author{
Ellen E. Kaulbach $\uparrow$
}

\section{INTRODUCTION}

In June 1978, Clyde Davis, a former employee of Ford Motor Company, filed suit in federal court alleging that his union had wrongfully expelled him in violation of the Labor-Management Reporting and Disclosure Act (LMRDA). ${ }^{1}$ On appeal from summary judginent, the Eleventh Circuit ruled that Davis' suit was barred by a six-month federal statute of hinitations. ${ }^{2}$

Had Davis brought an identical suit in the Second Circuit, however, his claim would have been governed by the forum state's statute of limitations for personal injury actions, ${ }^{3}$ and likely would have been timely. ${ }^{4}$ This inconsistent treatment of identical claims arises from the LMRDA's lack of an express statute of limitations, which forces courts to borrow a limitations period froin some other statute not applicable by its terms. ${ }^{5}$ Because the current doctrime governing selection of an appropriate himtations period is unclear, the circuit courts are in conflict regarding which period is appropriate to LMRDA claims, and even whether state or federal statutes should be the source of the limitation.

The LMRDA certainly is not umique in this respect. Many federal statutes that authorize civil causes of action lack limitations provisions. ${ }^{6}$

$\dagger$ B.A. 1980, Wesleyan University; third-year student, Boalt Hall School of Law, University of California, Berkeley. I would like to thank Prof. Stephen Bundy, Karen Kennard, and Jeff Lewis for their thoughtful comments and assistance.

1. 29 U.S.C. $\$ 401$ (1982).

2. Davis v. UAW, 765 F.2d 1510 (11th Cir. 1985), cert. denied, 475 U.S. 1057 (1986).

3. See Rodonich v. House Wreckers Union Local 95, 817 F.2d 967, 977 (2d Cir. 1987).

4. Statutes of limitations for personal injury usually permit the filing of a snit several years after discovery of the injury. See, e.g., N.Y. Crv. Prac. L. \& R. 214(5) (McKinney 1972) (providnig three-year limitations period for personal injury actions).

5. As discussed below, courts also have the option of applying no limitations period at all to a federal statutory claim. See infra notes 152-154 and acconipanying text.

6. See, e.g., Civil Rights Act of 1871, 42 U.S.C. $\$ \S 1981,1983,1985$ (1982) (civil actions for deprivation of civil rights); Labor Managenent Relations Act $\$ 301$ (a), 29 U.S.C. § 185(a) (1982) (civil actions for violations of contracts between eniployers and labor unions).

A general statute of limitations imposes a five-year limit on actions brought "for the enforcenient of any civil fine, penalty, or forfeiture" except as otherwise provided by Congress. 28 U.S.C. $\$ 2462$ (1982). Courts have interpreted this statute narrowly, and have applied it only to 
In general, however, courts have not interpreted congressional silence as indicating an intent to create unlimited rights of action. ${ }^{7}$ Without time limitations, a suit could be brought on stale evidence, creating the risk of an unjust result. Time limitations also promote stability, by protecting potential defendants froin exposure to liability for an indefinite period of time. $^{8}$ These considerations led Chief Justice Marshall to declare that a cause of action witlıout a tiıne limitation would be "utterly repugnant to the genius of our laws."

Due to the fundamental importance of time limitations on causes of action, courts generally presume that Congress intended some limitation to apply, even if it failed to provide one explicitly. Courts therefore have felt obliged to fill the gap. Nevertheless, courts recognize that they lack special coinpetence or estabhished principles by which to select a particular time limit, and thus they rely, where possible, on legislative judginent. $^{10}$ Accordingly, courts generally borrow statutes of limitations from causes of action inost analogous to the federal action in question.

Until 1983, federal courts rehed exclusively on state law as the source of limitations periods. ${ }^{11}$ To find an analogous state statute, courts generally characterized federal causes of action on the basis of the particular facts and legal theories involved in the action at bar; as a result, different limitations periods might govern various claims under a single federal statute. ${ }^{12}$ Courts disregarded state limitations periods only when their application would frustrate the underlying policies of the federal statute. ${ }^{13}$ When no appropriate state statute was available, inost courts

actions brought by or on behalf of the United States. See infra notes 205-206 and accompanying text. A general residual five-year statute of limitations also governs all federal criminal prosecutions of noncapital crimes. 18 U.S.C. $\$ 3282$ (1982).

7. See infra notes 29-31 and acconpanying text.

8. For discussions of the justifications for temporal linits on causes of action, see Fischer, The Limits of Statutes of Limitation, 16 Sw. U.L. Rev. 1, 2 (1986); Special Project, Time Bars in Specialized Federal Common Law: Federal Rights of Action and State Statutes of Limitations, 65 CORNEll L. REv. 1011, 1014-18 (1980) (authored by Mitchell A. Lowenthal, Brian E. Pastuszenski, and Mark E. Greenwald); Developments in the Law-Statutes of Limitation, 63 HARV. L. REv. 1177, 1185-86 (1950); Note, Limitation Borrowing in Federal Courts, 77 M1CH. L. REv. 1127, 1128-29 (1979). See also Burnett v. Grattan, 468 U.S. 42, 53 (1984); Burnett v. New York Cent. R.R., 380 U.S. 424, 428 (1965).

9. Adams v. Woods, 6 U.S. (2 Cranch) 336,342 (1805).

10. See infra notes $157-164$ and acconpanying text.

11. But cf. McAllister v. Magnohia Petroleum Co., 357 U.S. 221, 229 (1958) (Brennan, J., concurring) (suggesting that an analogous federal law could provide a limitations period for an unseaworthiness action).

12. See infra notes $43-47$ and accompanying text.

13. See, e.g., Occidental Life Ins. Co. v. EEOC, 432 U.S. 355 (1977). Courts also declined to apply state limitations that discriminated against federal rights. See Johnson v. Davis, 582 F.2d 1316, 1318 (4th Cir. 1978) (Virginia statute discriminated against federal civil rights actions); Caldwell v. Alabama Dry Dock \& Shipbldg. Co., 161 F.2d 83, 86 (5th Cir.) (Alabama statute discriminated against claims under the Fair Labor Standards Act), cert. denied, 332 U.S. 759 (1947). 
held that the action was not governed by any determinate time limitation..$^{14}$

In 1983, the Supreme Court departed from traditional borrowing doctrine in DelCostello v. International Brotherhood of Teamsters, ${ }^{15}$ by holding that a court may borrow a federal statute of limitations not hiterally applicable by its terıns. Two years later, in Wilson v. Garcia ${ }^{16}$ the Court declared that a uniforin characterization may govern a single federal statute for limitations purposes, regardless of the underlying facts or legal theories involved in a particular case. The Court reaffirmed both results in Agency Holding Corp. v. Malley-Duff \& Associates, ${ }^{17}$ where the Court applied the Clayton Act's four-year limitations period ${ }^{18}$ uniformly to all private civil enforcement actions brought under the Racketeer Influenced and Corrupt Organizations Act (RICO). ${ }^{19}$

Despite their apparent break with tradition, DelCostello and MalleyDuff retain the traditional analytic framework for choosing between state and federal limitations periods. Both cases authorize the use of a federal statute of limitations only when a state statute would frustrate the relevant federal policies. In addition, neither Wilson nor Malley-Duff resolve when a court should choose a uniforin characterization of a federal statute, rather than multiple characterizations tied to the underlying facts. This Comment argues that the Court should discard the automatic preference for state limitations periods and establish a more principled inethodology for characterizing federal statutes and borrowing statutes of limitations.

Statutes of limitations embody a legislature's balancing of the state's interests in repose and accurate, efficient prosecution of lawsuits, on the one hand, against the interests in preserving potential plaintiffs' right to sue and the vindication of governmental policies through those suits, on the other. ${ }^{20}$ Balancing these interests involves consideration of the governmental interests implicated; the difficulties involved in bringing a suit, including discovery of the injury and its source, and procedural requirements; and the life expectancy of evidence likely to be required. ${ }^{21}$ When

14. See, e.g., Caldwell, 161 F.2d at 86. If the court dechines to borrow a determinate limitations period, the cause of action might be governed by the equitable doctrine of laches. See, e.g., Occidental, 432 U.S. at 373.

15. 462 U.S. 151 (1983).

16. 471 U.S. 261 (1985).

17. 107 S. Ct. 2759 (1987).

18. 15 U.S.C. $\$ 15 b$ (1982).

19. 18 U.S.C. $\$ 1964$ (c) (1982).

20. See supra note 8 and accompanying text.

21. See, e.g., Burnett v. Grattan, 468 U.S. 42, 50-53 (1984) (discussing factors relevant to selection of limitations periods); Johnson v. Railway Express Agency, 421 U.S. 454, 463-64 (1975) (limitations period "reflects a value judgment concerning the point at which the interests in favor of protecting valid claims are outweighed by the interests in prohibiting the prosecution of stale ones"). 
a court borrows a limitations period from a statute not literally applicable, it relies on a legislative determination that presumably involved a balancing of interests similar to those interests raised by the statute in question. ${ }^{22}$ Unlike state statutes, federal statutes of limitations incorporate the weight of federal interests im the balance. Accordingly, this Comment argues that courts sliould abandon the presumption favoring state law. Courts should borrow time limitations from federal law whenever an existimg federal limitations period governs similar claims and when federal policies favor application of a uniforn federal period. In addition, this Comment proposes a clarification of the metlod of cliaracterizing federal claims for limitations purposes. Sucli an approach would enable courts to approximate better the balance between repose and prosecution that Congress miglit liave struck liad it considered the issue.

Part I of this Comment examines both the historical origins of the borrowing doctrine, and the analytic process courts employ to borrow analogous statutes of limitations. Part II discusses recent cases in which the Supreme Court lias borrowed federal statutes of himitations and the probleins this lias raised. It describes the failure of the recent cases to explain clearly how courts should choose between multiple and uniforn characterization of claims under a single federal statute, and to identify the factors relevant to the choice of a particular limitations period. Part III examines the doctrinal foundations of the borrowing doctrine, and concludes that courts should abandon the presumption in favor of state limitations periods. Nevertheless, it concludes that the analogy method of selecting limitations periods is sound, and sliould be employed regardless of the source of the borrowed limitations period. Part IV proposes an analytic framework for setting limitations periods that focuses inquiry on the interests of prosecution and repose.

I

\section{Traditional BorRowing Doctrine}

\section{A. Origins of the Presumption Favoring Application of State Law}

In the nineteentli and early twentieth centuries, courts held the view that state statutes of limitations as construed by state courts applied to federal causes of action, unless preempted by federal law. ${ }^{23}$ The Supreme Court held that the Rules of Decision Act $^{24}$ coinpelled this result in

22. See, e.g., Wilson v. Garcia, 471 U.S. 261, 271 (1985).

23. See, e.g., O'Sullivan v. Felix, 233 U.S. 318 (1914); Chattanooga Foundry and Pipe Works v. City of Atlanta, 203 U.S. 390 (1906); Campbell v. Haverhill, 155 U.S. 610 (1895); M'Cluny v. Silliman, 28 U.S. (3 Pet.) 270 (1830).

24. 28 U.S.C. \$ 1652 (1982). The Rules of Decision Act states: "The laws of the several states, except where the Constitution or treaties of the United States or Acts of Congress otherwise require 
Campbell v. Haverhill..$^{25}$ In applying the state limitations period to an action for patent infringeinent, the Court rejected plaintiff's argument that the states had no power to limit federally created rights. The Court ruled that state statutes of limitations "applied" within the meaning of the Rules of Decision Act, unless the state law discriminated against federal actions or was substantively unreasonable. ${ }^{26}$

The Supreme Court ultimately rejected the view that state limitations periods "apply" to federal statutory rights. In Holmberg v. Armbrecht, ${ }^{27}$ the Court explained that the limitation of a federal riglit was a matter of federal, not state, law. ${ }^{28}$ Congressional silence on the matter of limitations simply meant that Congress had left the matter to "judicial implications"; 29 in other words, courts were to draw upon federal common law to supply the omitted limitations period.

Under the Holmberg rationale, a court may "borrow" a state limitations period for a federal statute as a matter of federal pohicy; the state law does not apply of its own force. ${ }^{30}$ The court's ultimate goal is to enforce the federal statute im a manner that best effectuates the federal pohicies behind the statute im question. The Holmberg Court explained: "The implied absorption of State statutes of limitation within the imterstices of the federal enactments is a phase of fashioning remedial details where Congress has not spoken but left matters for judicial determination within the general frainework of familiar legal principles." ${ }^{31}$

One might expect that this recognition of the judicial power to "fashion[ ] remedial details" would have led to less borrowing from state law. Nevertheless, the practice of borrowing state limitations periods reinained prevalent. ${ }^{32}$ Courts apparently believed that absent adoption of a state limitations period, the right to sue under a federal statute that lacks an express limitation would be limited at most by the doctrine of

or provide, shall be regarded as the rules of decision in civil actions in the courts of the United States, in cases where they apply." Id.

25. 155 U.S. 610, 614-16 (1895).

26. Id. at 615. For a thorough discussion of the Campbell Court's rcasoning, see Special Project, supra note 8, at 1031-37.

In Agency Holding Corp. v. Malley-Duff \& Assocs., Justice Scalia noted that the Rules of Decision Act should affect only the precnution prong of the traditional borrowing doctrine. $107 \mathrm{~S}$. Ct. 2759, 2770-71 (1987) (Scalia, J., concurring).

27. 327 U.S. 392 (1946).

28. Id. at 394-95.

29. Id. at 395.

30. Id.

31. Id.

32. See Agency Holding Corp. v. Malley-Duff \& Assocs., 107 S. Ct. 2759, 2768-71 (Scalia, J., concurring) ("Prior to DelCostello, the virtually uniform practice was to look to applicable state statutes of limitations."). 
laches, ${ }^{33}$ or in soine cases, not limited at all. ${ }^{34}$ Because such a result was undesirable in light of the need for repose, adoption of state statutes of limitations inay have appeared to be the most reasonable option. Accordingly, the borrowing doctrine under Holmberg contained a presuinption in favor of borrowing state limitations.

\section{B. The Methodology of Borrowing}

\section{Drawing an Analogy}

Under the Holmberg borrowing doctrine, courts inust deternine which state law limitations period is "1nost appropriate"35 as a matter of federal law. This entails a search for similar, or "analogous," state law claims and their respective statutes of himitations. This analogy process enables a court to draw upon legislative judgments concerning the relative values of repose and the prosecution of claims, and hence, to approximate the balance appropriate to the federal cause of action. ${ }^{36}$ In order to select an appropriate state law limitations period, the court inust first characterize the essence of the federal action, and then examine potentially analogous state law actions. When inore than one potentially analogous state law action exists, the court will choose the one governed by a time period most appropriate to enforcement of the federal scheme in light of its underlying purposes. ${ }^{37}$

The analogy process atteinpts to match causes of action that are similar in terns of the importance of safeguarding plaintiffs' right to sue, defendants' interest in repose, evidentiary concerns, and practical probleins in hitigation. Courts try to locate actions involving the same types of behavior or harns, or which provide similar renedies, in the behef that they will refiect the saine coinbination of interests in encouraging prosecution of private clains, protecting defendants' interest in repose, and ensuring efficacious use of the evidence likely to be involved. ${ }^{38}$ Likewise, because private and "public law" claims inay reflect different federal interests, courts may take into account whether

33. The equitable doctrine of laches applies only to actions in equity. See County of Oneida v. Oneida Indian Nation, 470 U.S. 226, 244 n.16 (1985); Special Project, supra note 8, at 1027 n.82.

34. See Malley-Duff, 107 S. Ct. at 2771 (Scalia, J., concurring) ("[I]f . . the statc limitations period that would apply under state law is pre-empted because it is inconsistent with the federal statute, . . there is no limitation on the federal cause of action.").

35. Johnson v. Railway Express Agency, 421 U.S. 454, 462 (1974).

36. See Wilson v. Garcia, 471 U.S. 261, 271 (1985); Johnson, 421 U.S. at 463-64; see also Malley-Duff, 107 S. Ct. at 2771 n.3 (1987) (Scalia, J., concurring) (explaining differences between the Campbell and Holmberg approaches).

37. For example, in UAW v. Hoosier Cardinal Corp., 383 U.S. 696 (1966), the Court applied the state statute of limitatious for oral, rather than written, contracts to a union's breach of contract action against an employer. The Court reasoned that federal labor policy made the shorter limitations period for oral contracts more appropriate. Id. at 706-07.

38. See, e.g., Malley-Duff, 107 S. Ct. at 2764-65; Burnett v. Grattan, 468 U.S. 42, 53-54 (1984). 
the individual plaintiff vindicates public interests or merely seeks redress of private imjury. ${ }^{39}$ Finally, courts inay consider the practical limitations of the litigation-including the sophistication of the probable litigants, ${ }^{40}$ the burdens involved in filing a claim, ${ }^{41}$ and the need to join more than one claim. ${ }^{42}$

\section{Multiple Characterizations of a Single Act}

Under traditional doctrine, courts generally characterize a claim on the basis of the facts and legal theories involved in a given case, rather than establish a uniforin characterization for all claims under a particular federal statute. As a result, various limitations periods might apply to actions brought under a single federal statute, even within the saine state. $^{43}$ For example, in United Parcel Service v. Mitchell, ${ }^{44}$ the Supreme Court applied a ninety-day state statute of limitations to an action under the Labor Management Relations Act (LMRA) alleging unfair union representation, even though much longer state limitations periods apphied to other actions brought pursuant to the same federal act. ${ }^{45}$ Such fraginentation of a single federal statute-while justifiable in some instances $^{46}$ - nnay impede potential litigants from predicting the lifespan of outstanding claims, and thereby detract from the repose value of limitations periods. ${ }^{47}$

\section{Limits on the Application of Analogous State Law and Erosion of the Borrowing Doctrine}

Under the Holmberg borrowing doctrine, courts could decline to apply a potentially analogous state limitations period if the limitations would frustrate federal policy. ${ }^{48}$ Courts could reject state law not only

39. See Note, Statute of Limitations for Citizen Suits Under the Clean Water Act, 72 CORNELL L. REV. 195, 212 (1986) (authored by Carie Goodman McKinney).

40. See, e.g., DelCostello v. International Bhd. of Teamsters, 462 U.S. 151, 165-66 (1983) (contrasting unsophisticated individual employee with more sophisticated parties typically involved in commercial arbitration).

41. See, e.g., Burnett, 468 U.S. at 50-52 (noting that the burdens involved in seeking an administrative remedy are few relative to the burdens of filing a federal civil rights claim in court).

42. See, eg., DelCostello, 462 U.S. at 155; McAllister v. Magnolia Petroleum Co., 357 U.S. 221, 224-25 (1958).

43. See Special Project, supra note 8, at 1066-72, for a discussion of pre-Wilson characterization of civil rights claims.

44. 451 U.S. 56 (1981), overruled on other grounds DelCostello v. International Blid. of Teamsters, 462 U.S. 151 (1983).

45. See UAW v. Hoosier Cardinal Corp., 383 U.S. 696, 705-07 (1966) (applying a six-year state statute of limitations for contract actions cliarging breach of colleetive bargaining agreements under section 301(a) of the LMRA).

46. See infra text accompanying notes 171-182.

47. See Special Project, supra note 8 , at 1075.

48. E.g., Occidental Life Ins. Co. v. EEOC, 432 U.S. 355, 366-72 (1977); McAllister v. 
when it discriminated against federal rights or when it was clearly preempted by Congress; courts also could reject state law when it conflicted with implied congressional intent concerning the enforcement of federal statutory schemes.

In McAllister v. Magnolia Petroleum Co., ${ }^{49}$ for exanple, the Supreine Court found that application of a particular state statute of hmitations to a federal unseaworthiness claim would conflict with congressional policies embodied in an express limitations period governing a separate, but related, cause of action under the Jones Act. ${ }^{50}$ Although Congress had set a three-year limitations period for actions under the Jones Act, ${ }^{51}$ no exphicit federal limitations period governed unseaworthiness claims. The Court held that simce, as a practical inatter, both actions had to be brought $i m$ the same proceeding, state limitations that ran less than three years could not apply to the joined unseaworthiness claim. ${ }^{52}$ It reasoned that a shorter himitations period for unseaworthiness actions would contravene congressional intent to allow three years to sue under the Jones Act. ${ }^{53}$ Thus, the Court found a direct conflict between apphication of a particular state law and the interests protected by a federal statute of limitations, and declined to apply the state law.

The Court found a similar conflict between application of state law and implied congressional intent in Occidental Life Insurance Co. $\nu$. EEOC. ${ }^{54}$ The Court ruled that application of a California limitations period of 300 days to enforcement actions brought by the Equal Einployinent Opportunity Commission (EEOC) under titie VII of the Civil Rights Act of $1964^{55}$ would conflict with the federal policy favoring conciliation and admmistrative remedies. ${ }^{56}$ Here, however, the federal policy being frustrated was not a specific, congressionally enacted

Magnolia Petroleum Co., 357 U.S. 221, $225-26$ (1958); Holmberg v. Armbrecht, 327 U.S. 392, 395 (1946).

49. 357 U.S. 221 (1958).

50. The Jones Act provides that "[a]ny seaman who slall suffer personal injury in the course of his employment may .. . maintain an action for damages at law." 46 U.S.C. $\S 688$ (a) (1982). An unseaworthiness claim is an action under general maritime law alleging the shipowner's or operator's breach of the implied warranty that the vessel is reasonably fit for its intended use. See Mitchell v. Trawler Racer, Inc., 362 U.S. 539, 550 (1960). See generally T. SCHOENBAUM, ADMIRALTY AND MARITIME LAW $\S \S 4-5,5-3$ (1987).

51. According to the Supreme Court, the Jones Act, 46 U.S.C. $\S$ 688(a) (1982), incorporated by reference the statute of limitations for suits under the Federal Employers' Liability Act, 45 U.S.C. $\S 56$ (1982). See McAllister, 357 U.S. at 225 n.6. In 1980, Congress enacted a limitations period for personal injury and wrongful death suits arising from maritime torts. Pub. L. No. 96-382, § 1, 94 Stat. 1525 (1980) (codified at 46 U.S.C. $\S 763 a$ (1982)).

52. McAllister, 357 U.S. at 225-26.

53. Id.

54. 432 U.S. 355 (1977).

55. 42 U.S.C. $\S 2000 \mathrm{e}-5(\mathrm{f})(1)(1982)$.

56. Occidental, 432 U.S. at $367-72$. 
limitations period as in McAllister, but a general federal policy as expressed in the provisions of title VII taken as a whole.

The Occidental Court concluded from the lack of a suitable state law analogy that Congress had inade an affirmative decision not to limit the action in question. The Court stated that the EEOC was known to be burdened witlı a heavy workload, and that the legislative history disclosed congressional concern with the potential for delay. ${ }^{57}$ Moreover, the Court noted that Congress had enacted time limits only for the early stages of administrative proceedings, and had failed to limit other remedies under title VII. ${ }^{58}$ Nevertheless, in light of the usual presumption that Congress intends some time limit to apply to federal actions, ${ }^{59} \mathrm{imph}-$ cations drawn froin the general tenor of the statutory scheine would seein rather slim evidence on which to infer congressional intent to leave EEOC actions coinpletely unlimited.

In general, the Occidental Court appears to have been less than enthusiastic about applying the borrowing doctrine. The Court did not limit its holding to rejection of a particular state's limitations; ratlier, it implied that all state limitations, regardless of their length, would violate federal policy regarding EEOC actions. ${ }^{60}$ The Court noted that "[s]tate legislatures do not devise their limitations periods with national interests in mind," 61 and concluded that it would be unreasonable to suppose tliat Congress would "consign [the EEOC's] federal lawsuits to the vagaries of diverse state limitations statutes, some as short as one year."62 These observations appear to disclose a general dissatisfaction with the borrowing doctrine because of its failure to accommodate uniquely federal imterests and to provide uniforin treatment of identical actions in different states.

Unfortunately, the Occidental Court did not suggest a viable alternative to state law borrowing. Its holding that the equitable doctrine of laches would limit EEOC actions ${ }^{63}$ does not provide an adequate substitute for a defined limitations period; the discretionary, case-by-case application of laches offers neither the uinformity nor the notice necessary to promote interests in repose. ${ }^{64}$ Sucli difficulties might liave been avoided had the Court considered borrowing a limitations period froin a federal statute of limitations.

57. Id. at $369-70$.

58. Id. at 371-72.

59. See infra note 151 and accompanying text.

60. Occidental, 432 U.S. at 368-372.

61. Id. at 367.

62. Id. at $370-71$.

63. Id. at 373.

64. See Note, supra note 8, at $1143-45$ (criticizing Occidental's adoption of laches as substitute for a statutory limitations period). 
II

\section{Recent Changes IN THe Borrowing Doctrine}

In the mid-1980s, the Supreme Court started to alter the traditional borrowing doctrine, first by suggesting that limitations periods may be borrowed from federal statutes not directly applicable, ${ }^{65}$ and then by asserting that in at least some cases, a single characterization should govern all causes of action brought under a statute, regardless of the nature of the underlymg clamis. ${ }^{66}$ The Supreme Court, lowever, has failed to apply consistently a principled methodology for characterizing federal statutory claims for limitations purposes, or for deciding between federal and state limitations periods.

\section{A. DelCostello: Federal Law as an Alternative Source of a Borrowed Limitations Period}

The Supreme Court first turned to federal statutory law as a source for a borrowed limitations period in DelCostello v. International Brotherhood of Teamsters. ${ }^{67}$ DelCostello had lost his job as a driver after he refused to operate a tractor-trailer that he contended was unsafe. ${ }^{68}$ After his union unsuccessfully brought a formal grievance against the employer under procedures established by the collective bargaining agreement, DelCostello brought suit im federal court against his employer, for breach of contract, and against his union, for breach of its duty of fair representation. ${ }^{69}$ This type of suit is generally known as a "hybrid" section 301/ fair representation action. The claim against the employer is based on section 301 of the Labor Management Relations Act (LMRA); ${ }^{70}$ the action for breach of the union's duty of representation is implied under

65. DelCostello v. International Bhd. of Teamsters, 462 U.S. 151 (1983).

66. Wilson v. Garcia, 471 U.S. 261 (1985).

67. 462 U.S. 151 (1983). The DelCostello Court tried to mininize the impact of its holding by suggesting that it was not departing from traditional borrowing practice. See id. at 171. The Court stated that "in soine cases we have declined to borrow state statutes but have instead used timeliness rules drawn froin federal law-either express limitations periods from related federal statutes, or such alternatives as laches." Id. at 162 . The Court apparently reinterpreted its holding in McAllister v. Magnolia Petroleum Co., 357 U.S. 221 (1958), as applying the Jones Act statute of limitations to all unseaworthiness actions. The Magnolia opinion, however, stressed that it inerely found that state limitations periods of less than thrce years had been precmpted by Congress. Compare DelCostello, 462 U.S. at 162, with McAllister, 357 U.S. at 224 ("[W]e sinply hold that where an action for unseaworthiness is coinbined with an action under the Jones Act a court cannot apply to the former a shorter period of limitations than Congress has prescribed for the latter."). Thus, despite the DelCostello Court's protests to the contrary, DelCostello was the first case in which the Supreme Court affirmatively borrowed a limitations period froin a federal statutory source.

68. DelCostello, 462 U.S. at 155.

69. Id. at 155-56.

70. Section 301 of the Labor Management Relations Act (LMRA) authorizes suit in federal court for breach of a collective bargaining agreement. 29 U.S.C. $\$ 185$ (1982). 
the scheme of the National Labor Relations Act. ${ }^{71}$ Neither claim is governed by an express federal limitations period. In DelCostello, the Supreme Court held that the six-month federal statute of limitations for filing unfair labor practice complaints with the National Labor Relations Board (NLRB) ${ }^{72}$ should apply, by analogy, to both claims. ${ }^{73}$

By using a federal statute as the source of a borrowed limitations period, the Supreme Court attempted to address the problems with borrowing state law it had raised in Occidental Life Insurance Co. v. EEOC. However, the DelCostello Court stressed that it was not "depart[ing] from prior practice in borrowing limitations periods for federal causes of action .... [R]esort to state law remains the norm for borrowing of limitations periods."74 Federal law would be apphed only when (1) a federal rule "clearly provides a closer analogy than available state statutes,"75 and (2) "the federal pohcies at stake and the practicalities of hitigation make that rule a significantly more appropriate vehicle for interstitial lawmaking."76 The DelCostello Court thus maintained a presumption in favor of state law, but softened, somewhat, the preemption method of analysis used in earher cases. Under DelCostello, courts may reject a state time limitation not only when it is in direct conflict with federal policy, but also when the state limitations period is significantly less appropriate than a specific federal alternative.

The DelCostello test thus requires a comparison between potentially analogous federal and state causes of action, and suggests that a court must find the state law analogy flawed before considermg federal law alternatives. ${ }^{77}$ The Court's apphication of the test remforced the notion

71. DelCostello, 462 U.S. at $164 \&$ n.14. In order to recover damages against either the employer or the union, the plaintiff employee must prove both that the employer breached the collective bargaining agreement and that the union breached its duty of fair representation. See id. at 164-65; Vaca v. Sipes, 386 U.S. 171 (1967).

72. 29 U.S.C. $\$ 160(b)$ (1982).

73. DelCostello, 462 U.S. at 155.

74. Id. at 171.

75. Id. at 172 .

76. Id.

77. See id. at 165-66 (analogy to commercial arbitration flawed); id. at 167-68 (analogy to malpractice action flawed). This approach causes difficulties when a potentially suitable federal analog exists, but is not clearly a "closer analogy" than state law. For example, an action by a union to compel arbitration under a colleetive bargaining agreement appears very similar to state actions to compel arbitration under other contracts. Both are court actions to enforce the arbitration clause of a frecly negotiated agreement. The only apparent distinction is that the terms of a collective bargaining agrecment are a matter of federal law, while other contracts are governed by state law. An analogy to filing an unfair labor practice clain with the NLRB seenis a less perfect fit because unfair labor practice clainis often address a broad range of behavior other than refusal to arbitrate. See National Labor Relations Act $\S 8,29$ U.S.C. $\S 158$ (1982) (listing unfair labor practices). Even an analogy to claims under the Federal Arbitration Act (FAA), 9 U.S.C. $\$ 1$ (1982), seems nuerely as good as the state analogy, not clearly better. The FAA does not apply by its terms because it specifically excludes "contracts of employment." Id. Whether the court chooses a state law 
that use of federal law was an exception, rather than a new rule. The Court first examined the possible analogies to state law, but found those analogies flawed and unable to accommodate the practicalities of litigation in a hybrid section 301/fair representation action. ${ }^{78}$ The Court then found that section 10(b) of the National Labor Relations Act ${ }^{79}$ provided a particularly well-suited analogy: It governed similar underlying conduct, $^{80}$ represented congressional balancing of similar interests, ${ }^{81}$ and proinoted national uniformity in federal labor law. ${ }^{82}$

The Court's analysis of the analogies ultimately collapsed into the second step of its borrowing process: an analysis of federal policies at stake, the practicalities of hitigation, and the relative capacity of the available statutes-both state and federal-to accommodate these concerns. The Court noted that plaintiffs in hybrid suits are generally less sophisticated than the parties in commercial arbitration, and therefore need more time to file suit. ${ }^{83}$ On the other hand, the Court acknowledged that federal labor policy favors rapid resolution of disputes. ${ }^{84}$ The Court then examined the particular time limits set by the potentially analogous federal and state statutes to find the best option. The Court rejected both the relatively long state limitations period for contracts actions and the

limitation governing arbitration or a limitations period under the FAA, it is choosing a limitations period for arbitration of nonlabor contract disputes.

Thus, the DelCostello test would appear to require state limitations periods in such cases. Nevertheless, some circuits have reached different results. See, e.g., American Postal Workers Union v. United States Postal Service, 823 F.2d 466, 475-76 (11th Cir. 1987) (applying FAA limitations period to union suit to vacate arbitration award); McCreedy v. Local 971, 809 F.2d 1232, 1237-39 (6th Cir. 1987) (applying section 10(b) of the National Labor Relations Act to union suit to compel arbitration); Teamsters Local 315 v. Great Western Chem. Co., 781 F.2d 764, 769 (9th Cir. 1986) (same); Federation of Westinghouse Indep. Salaried Unions v. Westinghouse Elec. Corp., 736 F.2d 896, 901 (3d Cir. 1984) (same). But see Sheet Metal Workers Int'l Ass'n Local 150 v. Air Sys. Eng'g, 831 F.2d 1509, 1512 (9th Cir. 1987) (applying state law to union action to enforce arbitration award); Champion Int'1 Corp. v. United Paperworkers Int'l Union, 779 F.2d 328, 331-32 (6th Cir. 1985) (applying state law to employer snit to vacate arbitration award).

78. First, the Court noted that the hybrid action has no close analogy in "ordinary" state law. DelCostello, 462 U.S. at 165. Moreover, separate analogies for each half of the hybrid action would not serve well. The 90-day limitations period for state law actions to vacate a commercial arbitration award was too short to allow the generally unsophisticated plaintiff im a hybrid action to vindicate rights against an employer. Id. at 165-66. Although a inalpractice action was a fairly close state law analogy to the suit against the union, the umion could not be held liable for damages attributable to the employer's breach. Therefore, as a practical matter, the plaimtiff would normally bring suit against both defendants simultaneously, and would be governed by the shorter limitations period. Id. at 164-65. Finally, a relatively long limitations period for suit against the union would conflict with federal policy favoring rapid resolution of labor disputes. Id. at 168.

79. 29 U.S.C. $\$ 160(b)(1982)$.

80. DelCostello, 462 U.S. at 170.

81. Id. at 171 (quoting United Parcel Service v. Mitchell, 451 U.S. 56, $70-71$ (1981) (Stewart, J., concurring)).

82. Id.

83. Id. at $165-66$.

84. Id. at 168. 
relatively short state period for vacation of arbitration awards, saying, "it does not follow that because 6 years is too long, 90 days is long enough." 85 The Court concluded that the six-month period established in section 10(b) of the National Labor Relations Act ${ }^{86}$ for filing unfair labor practice claims with the NLRB was the proper length of time, and therefore, the proper period to be borrowed for "hybrid" actions..$^{87}$

\section{B. Wilson: Uniform Characterization of All Claims Under a Statute}

DelCostello followed the traditional route of characterizing claims individually on the basis of their underlying facts in order to determine the apphicable limitations period. Accordingly, DelCostello distinguished, rather than overruled, UAW v. Hoosier Cardinal Corp. ${ }^{88}$ which had applied the state limitations for oral contracts to "straightforward" actions under section 301 of the LMRA for breach of a collective bargaining agreement. ${ }^{89}$ Thus, DelCostello does not require use of federal limitations periods for all labor law actions, or even all actions under section 301. Rather, courts must distinguish "straightforward" claims, which are governed by state limitations, from less straightforward claims, which require appication of section 10(b).

The Supreme Court departed from this traditional claim-by-claim analogy method in Wilson v. Garcia, ${ }^{90}$ holding that all section 1983 civil rights claims ${ }^{91}$ should be characterized as actions sounding im tort, regardless of the underlying facts. ${ }^{92}$ The Court noted that many different types of claims could be brought under section 1983, each of which imght easily be analogized to a different common law form of action. ${ }^{93}$ Multiple limitations periods could therefore apply to various section

85. Id. at 166. The Court also found that a three-year period for a malpractice action was too long. Id. at 168.

86. 29 U.S.C. \& 160(b) (1982).

87. DelCostello, 462 U.S. at $169-72$.

88. 383 U.S. 696 (1966).

89. Id. at 705-07. Nevertheless, at least one circuit court has stated that DelCostello calls into question the continued applicability of Hoosier Cardinal. See Federation of Westinghouse Indep. Salaried Unions v. Westinghouse Elec. Corp., 736 F.2d 896, 900-01 (3d Cir. 1984). The Third Circuit noted the somewhat cryptic statement in footnote 12 of the DelCostello opinion: "[E]ven if this action were considered as arisuig solely under $\S 301$ [of the Labor Management Relations Act], ... the objections to use of state law and the availability of a well-suited limitations period in $\S 10(b)$ would call for application of the latter rule." 736 F.2d at 901 (quoting DelCostello, 462 U.S. at 158 n.12). See also Comment, $A$ Plea for a Uniform Statute of Limitations for Private Causes of Action Under the NLRA, 54 Miss L.J. 265, $277-87$ (1984) (authored by Richard B. Hankins) (suggesting that DelCostello's rationale for applying section 10(b) could extend to all actions under sections 301 and 303 of the LMRA).

90. 471 U.S. 261 (1985).

91. 42 U.S.C. $\S 1983$ (1982).

92. Wilson, 471 U.S. at 276.

93. Id. at $272-74$. 
1983 claims within the same state, and even within the same case. ${ }^{94}$ The Court found this unacceptable. According to the Court, federal interests in "uniformity, certainty, and the minimization of unnecessary litigation" supported using a single characterization for all clains brought under the statute, regardless of the underlying facts or legal theories asserted. ${ }^{95}$

Nevertheless, the Court held that state limitations should apply despite a resulting lack of uniformity between states. Virtually ignoring DelCostello, ${ }^{96}$ the Wilson Court did not examine whether any federal statute of limitations would provide a closer analogy. It simply declared that "the settled practice has been to adopt a local time limitation as federal law if it is not inconsistent with federal law or policy to do so."97 The Court found that Congress had "imphicitly endorsed" the borrowing of state limitations periods through section 1988 of the Reconstruction Civil Rights Acts, which instructs courts to look to state law when no suitable federal rule of decision is available. ${ }^{98}$ After examining " $\mathrm{t}$ ] atrocities that concerned Congress in 1871,"99 the Court found that section 1983 civil rights claims are most analogous to state law tort claims for personal injury. ${ }^{100}$

\section{Malley-Duff: Combining the Wilson and DelCostello Approaches}

In Agency Holding Corp. v. Malley-Duff \& Associates, ${ }^{101}$ the Court coinbined the Wilson and DelCostello approaches to determine the appropriate limitations period for claims under the Racketeer Influenced and

94. Id. at 274 .

95. Id. at 275 .

96. The Wilson Court cited DelCostello only briefly in support of the view that characterization of a federal claim for limitations purposes is a question of federal law. Id. at 270 \& n.21.

97. Id. at 266-67.

98. Id. at 267. Section 1988 provides, in relevant part:

The jurisdiction in civil and criminal matters conferred on the district courts ... for the protection of all persons in the United States in their civil rights, and for their vindication, shall be exercised and enforced in conformity with the laws of the United States, so far as such laws are suitable to carry the same into effect; but in all cases where they are not adapted to the object, or are deficient in the provisions necessary to furnish suitable remedies and punish offenses against law, the common law, as modified and changed by the constitution and statutes of the State wherem the court having jurisdiction . . . is held, so far as the same is not inconsistent with the Constitution and laws of the United States, shall be extended to and govern the said courts in the trial and disposition of the cause . . . .

42 U.S.C. $\S 1988$ (1982). Despite the Court's reasoning in Wilson, the borrowing of a federal limitations period would not be imconsistent with section 1988, since that section directs courts to consider federal rules of decision first. For a discussion of Congress' intent in drafting section 1988, see Eisenberg, State Law in Federal Civil Rights Cases: The Proper Scope of Section 1988, 128 U. PA. L. REV. 499, 525-543 (1980).

99. Wilson, 471 U.S. at 277.

100. Id.

101. 107 S. Ct. 2759 (1987). 
Corrupt Organizations Act (RICO). ${ }^{102}$ First, the Court examined whether all claims arising under RICO should be characterized uniformly ${ }^{103}$ Second, the Court considered whether a federal or state statute of limitations should be apphed. ${ }^{104}$ The Court concluded that all civil RICO claims should be treated alike, and that the Clayton Act's four-year limitations period for civil remedies provided the best analogy. ${ }^{105}$

The Malley-Duff Court retained DelCostello's presumption in favor of state law, stating that state law should be rejected ouly "[i]n some limited circunistances," where it is at odds with federal pohicy. ${ }^{106}$ However, the Court's analytic approach differed from that taken in DelCostello: The Court examined federal law first, rather than state law, to find an appropriate analogy. The Court found that the Clayton Act provided a very close analogy in light of Congress' rehance on the language of that Act in drafting RICO, and the similarity in the remedies and liarms addressed by the two statutes. ${ }^{107}$ After identifying this close federal ana$\log$, the Court noted the lack of a "comparable single state law analogue to RICO." 108 The Court also found that the practicalities of RICO litigation, which often involves interstate transactions, counseled use of a single federal limitations period. ${ }^{109}$

\section{Problems Raised by Recent Decisions}

The varying approaches taken by the Supreme Court in the cases discussed above create several problems both in choosing between federal and state law as the source of borrowed limitations, and in the analogy process. The following section addresses these issues $\mathrm{m}$ turn.

\section{State vs. Federal Limitations Periods}

The current framework for deciding between state and federal limitations periods, as defined by the Court in Malley-Duff, Wilson, and DelCostello, has several serious flaws. First, it retains the presumption favorimg state law as a source of borrowed limitations periods. ${ }^{110}$ This presumption may liave served a practical purpose when the body of fed-

102. 42 U.S.C. $\S 1985$ (1982).

103. Malley-Duff, 107 S. Ct. at 2763-64.

104. Id. at 276466 .

105. Id. at 2767.

106. Id. at 2762.

107. Id. at 2764-65.

108. Id. at 2765 . The Court refused to apply the state's catch-all statute of limitations, noting that not all states have such a statute. Id.

109. Id. The Court distimguished Wilson on the ground that section 1983 actions, unlike RICO actions, do not require an interstate commerce nexus. Id. at 2766.

110. See id. at 2762; Wilson v. Garcia, 471 U.S. 261, 266-67 (1985); DelCostello v. International Bhd. of Teamsters, 462 U.S. 151, 171-72 (1983). 
eral statutory law was small and, hence, unlikely to provide a viable alternative source of limitations. With the growth of federal statutory law and the mcreased availability of potential federal law analogs, however, such a presumption is no longer necessary. In addition, as Part III demonstrates, the presumption is not doctrinally required. Because state legislatures cannot properly take uniquely federal interests imto account when setting time limits for causes of action, and because the adoption of state rules causes a lack of uniformity in the enforcement of federal rights, state rules should be adopted only when federal policies so require.

Second, because the current frainework requires a comparison between specific state and federal law alternatives, the choice between federal and state limitations periods for a particular statute depends on the happenstance of where a suit arises. For example, in Malley-Duff, if the forum state had had a "mini-RICO" antiracketeering remedy, the applicable statute of limitations arguably would have provided a very close analogy to the claim at bar. Would this have required apphication of a state law period? Similarly, had the Wilson claim arisen in Utah, which has no statute of limitations for personal injuries, would the Court have found that a federal rule should apply? These problems arise because the Supreme Court has retained the traditional borrowing methodology despite the fact that adding federal law to the choice of analogous statutes distorts that methodology.

The problems with the existing doctrine are further compounded if the court focuses on the actual time limits when choosing between federal law and the law of a particular state, as the Supreme Court did in DelCostello. ${ }^{111}$ As the DelCostello Court noted, at least two states have limitations periods longer than nimety days for vacation of arbitration awards. ${ }^{112}$ The Court's rehance on the actual time limits involved imphes that state law might have been adopted had the case arisen in one of those states. The length of a particular state period is relevant only to whether that period is appropriate, and is not helpful in deciding between federal and state law as the proper source of the limitations period. ${ }^{113}$

\section{The Analogy Method}

\section{a. Choosing an Analogous Statute}

The recent Supreine Court cases have failed to provide clear guidance on how to choose an analogous statute for limitations purposes. An

111. See supra notes $85-87$ and accompanying text.

112. DelCostello, 462 U.S. at 166 n.15 (1983).

113. Cf. Sheet Metal Workers Int'1 Ass'n Local 150 v. Air Sys. Eng'g, 831 F.2d 1509, 1512-13 (9th Cir. 1987) (choosing state limitations period, although the potentially analogous federal statute provided the same limitations period). 
instructive decision should identify the considerations involved in the choice of a limitations period and thereby explain the Court's process of decision. The Supreme Court has had mixed results in its attempts at articulating the relevant considerations and thus it has been completely unsuccessful in establishing a workable process.

In DelCostello, the Supreme Court adequately identified the factors relevant to time limits; the Court considered the sophistication of the plaintiff, the remedies available, and the burdens imvolved in filing suit. ${ }^{114}$ Nevertheless, the Court's two-prong test obscures, rather than clarifies, the process of decision. As previously discussed, the DelCostello test requires the court to consider (1) the aptness of potential state and federal analogs and (2) whether specific limitations periods accommodate federal policies and the practicalities of hitigation. ${ }^{115}$ The test's formulation suggests that the court must perform two separate imquiries. In fact, however, the court performs only one imquiry: how effectively the statute of limitations furthers federal goals. A court cannot evaluate the aptness of an analogy for limitations purposes until it examines relevant federal policies and the practicalities of hitigation. Because the DelCostello Court failed to articulate the analogy process clearly, lower courts have had difficulty interpreting the DelCostello opimion, and have disagreed about which factors were critical to the Court's characterization of the claim. ${ }^{116}$

114. DelCostello, 462 U.S. at 165-68.

115. Id. at 172; see supra text accompanying notes $75-76$.

116. Lower courts differ regarding which factors are critical to the DelCostello Court's characterization of straightforward section 301 claims, which are governed by state law contract limitations, and claims that are not straightforward. Some view DelCostello as creating a special exception for suits brought by employees, as opposed to suits by unions or employers. See, e.g., Champion Int'l Corp. v. Umited Paperworkers Int'l Umion, 779 F.2d 328, 332 (6th Cir. 1985) (DelCostello reasoning does not apply to employer action against union to vacate an arbitration award since both parties are sophisticated); International Union of Elec. Workers v. Ingram Mfg. Co., 715 F.2d 886, 888 (5th Cir. 1983) (DelCostello distinguished cases brought by entployees from typical union or entployer suits), cert. denied, 466 U.S. 928 (1984). Sone courts exaumine whether the underlying conduct bears a "family resemblance" to unfair labor practice claims governed by section 10(b). See, e.g., Grasty v. Amalgamated Clothing \& Textile Workers Union, 828 F.2d 123, 132 (3d Cir. 1987) (claims alleging breach of union constitution would support claim for violation of duty of fair representation), cert. denied, 108 S. Ct. 773 (1988); Reed v. United Transp. Union, 828 F.2d 1066, 1069-70 (4th Cir. 1987) (claim under the Labor-Managenient Reporting and Disclosure Act (LMRDA) resembles unfair labor practice claim), cert. granted, $108 \mathrm{~S}$. Ct. 1105 (1988); Local 1397, United Steelworkers v. United Steelworkers, 748 F.2d 180, 183 (3d Cir. 1984) (same); Adkins v. International Union of Elec. Workers, 769 F.2d 330, 335 (6th Cir. 1985) (DelCostello apphes to all unfair representation claims).

Other courts focus on DelCostello's rationale for the need for uniformity in certain labor law matters: the federal policy to promote the "consensual processes" of forming collective agreenents and settling disputes privately under those agreements. DelCostello, 462 U.S. at 162-63 (quoting UAW v. Hoosier Cardinal Corp., 383 U.S. 696, 702 (1966)). These courts ask whether the claim is likely to disrupt an established labor-management relationship or dispute resolution mechanism. See, e.g., Lewis v. International Bhd. of Teamsters, Local 771, 826 F.2d 1310, 1316 (3d Cir. 1987) 
In the later cases, Wilson and Malley-Duff, the Supreme Court failed to identify the considerations relevant to characterization of claims altogether. The Wilson Court never addressed whether concerns relevant to the choice of a limitations period, such as lifespan of evidence and difficulties of discovering injury, are similar in inost section 1983 and tort cases. ${ }^{117}$ Moreover, the Court conceded that the federal imterest in prosecution of section 1983 claims could not have been taken into account by the state legislatures that set limitations periods for tort claims. ${ }^{118}$

The Malley-Duff Court similarly failed to apply the analogy method in sufficient depth. Although it properly considered the types of remedies available as an indication of the importance Congress attached to the cause of action, ${ }^{119}$ it failed to discuss whether similar kinds of evidence would be involved in prosecuting RICO and Clayton Act claims, or whether similar types of plaintiffs or defendants were likely to be involved. In other words, it ignored many of the practical aspects of hitigation. As a result, the Court failed in both Wilson and Malley-Duff to provide an adequate inodel for application of the borrowing doctrine.

\section{b. Uniform vs. Multiple Characterization}

Neither Wilson nor Malley-Duff clarified when courts should characterize all claims under a statute uniformly. If a statute regularly gives rise to different types of claims that legitimately might be characterized

(suit for breach of union constitution could affect bargaining relationship with employer); American Postal Workers Union v. United States Postal Serv., 823 F.2d 466, 474-75 (1 Ith Cir. 1987) (applying the shorter uniform federal limitations period to a suit to vacate arbitration award because federal labor law is designed to promote private dispute settlement); Rodonich v. House Wreckers Union Local 95, 817 F.2d 967, 976 (2d Cir. 1987) (decliming to apply section 10(b) to LMRDA action since it has no "immediate and direct impact on labor-management relations"); Doty v. Sewall, 784 F.2d 1, 7 (1st Cir. 1986) (LMRDA action “in no way challenges the 'stable relationship' between employer and union"); Monarch Long Beach Corp. v. Soft Drink Workers, Local 812, 762 F.2d 228, 231 (2d Cir.) (declining to apply section 10(b) to section 303 action between "parties who are otherwise completely unrelated"), cert. denied, 474 U.S. 1020 (1985).

Because of the difficulties involved in interpreting DelCostello, and the Court's admonition that it was not signaling a departure from traditional borrowing doctrine, several circuits have asserted that DelCostello should be read narrowly. See, e.g., Niro v. Fearn Int'l, 827 F.2d 173, 177 (7th Cir. 1987) ("This circuit has been properly circumspect . . . about extending the six-month limitations period to causes of action other than the hybrid section 301 suit . . . "); Doty, 784 F.2d at 6 ("DelCostello is not the kind of precedent that lends itself as a springboard for easy application to other rights, statutes, and policies."); Carruthers Ready-Mix, Inc. v. Cement Masons Local 520, 779 F.2d 320, 327 (6th Cir. 1985) ("DelCostello is not a 'green light' to apply 29 U.S.C. $\$ 160$ (b) to all actions in which federal labor law is implicated.").

117. Cf. Okure v. Owens, 816 F.2d 45, $48-49$ (2d Cir. 1987) (applying limitations period governing general torts instead of period governing intentional torts because of difficulty involved in recognizing seetion 1983 claims), cert. granted, $108 \mathrm{~S}$. Ct. 1218 (1988). But cf. Gates v. Spinks, 771 F.2d 916, 919-20 (5th Cir. 1985) (choosing limitations period governing intentional torts), cert. denied, 475 U.S. 1065 (1986).

118. Wilson v. Garcia, 471 U.S. 261, $272 \&$ n.24 (1985).

119. Agency Holding Corp. v. Malley-Duff \& Assocs., 107 S. Ct. 2759, 2764 (1987). 
in different ways, it would appear intuitively that multiple, fact-specific characterizations would be preferable to a uniform approach. ${ }^{120}$ The Supreme Court, however, ignored this distinction, stating in both Wilson and Malley-Duff that uniform characterization was necessary to avoid "uncertainty and time-consuming litigation." 121 This rationale proves too inuch; if the Court's main concern was to eliminate uncertainty and litigation over limitations periods, it would have been far simpler to adopt a single period for all federal statutes lacking express limitations provisions. Nevertheless, the exacting analogy process remains valid because of the Court's implicit behief that more precise legislative judgments about the relative values of repose and prosecution are necessary to effectuate federal pohicy.

In the naine of simplicity and uniformity, the Supreme Court has offered two new options to federal courts: uniform characterization of claims under a single statute, and apphication of federal time limits. The Court has offered little guidance, however, on when courts should eniploy these options instead of applying state law or characterizing claims individually on the basis of the underlying facts. Thus the Court has failed to provide the clarity and predictability it has declared is necessary to alert potential plaintiffs of their rights and to serve potential defendants' interests in repose. ${ }^{122}$

Nevertheless, the recent Suprenie Court cases discussed here reveal an increased sensitivity to the special nature of federal statutory rights, and skepticism that state legislatures can balance properly the values of federal rights against the values of repose. These cases also reveal a desire for uniformity in treatment of different causes of action arising under a single statute. The Supreme Court has granted certiorari in two cases that involve limitation of federal statutory causes of action; ${ }^{123}$ this seems to suggest an awareness of the Court's failure to articulate clear guidelines for borrowing statutes of limitations. In reviewing these cases, the Suprene Court could further the goals of uniformity and predictability by abandoning the presumption favoring application of state law, and by adopting a more functional approach toward the analogy process. One such approach is presented in Part IV. Part III denionstrates that there is no legal, doctrinal restriction that prevents the Court from abandoning the presuniption favoring state law for a functional approach.

120. See Wilson, 471 U.S. at 282-84 (O'Connor, J., dissenting).

121. Malley-Duff, $107 \mathrm{~S}$. Ct. at 2764 (quoting Wilson, 471 U.S. at 272).

122. See Wilson, 471 U.S. at 270 (asserting the federal interest in having " "firmly defined, easily applied rules'" for limitations of actions) (quoting Chardon v. Fumero Soto, 462 U.S. 650, 667 (1983) (Rehnquist, J., dissenting)).

123. Reed v. Umited Transp. Umion, 828 F.2d 1066 (4th Cir. 1987), cert. granted, $108 \mathrm{~S}$. Ct. 1105 (1988); Okure v. Owens, 816 F.2d 45 (2d Cir. 1987), cert. granted, 108 S. Ct. 1218 (1988). 
III

\section{DOCTRINAL FOUNDATIONS}

\section{A. Doctrinal Sources of the Presumption Favoring State Law Limitations}

Whenever a federal statute fails explicitly to provide a rule necessary to the determination of rights and habilities under that statute, courts must fill the gap from some other source of law. Two potential restrictions on the court's choice of a limitations period are the Rules of Decision $\mathrm{Act}^{124}$ and principles of statutory construction related to congressional silence. Nevertheless, as the following discussion demonstrates, neither the Rules of Decision Act nor implications froin congressional silence require a preference for state limitations periods. Courts therefore are free to select a limitations period from federal law whenever it would best serve federal interests.

\section{The Rules of Decision Act}

The Rules of Decision Act neither requires nor prohibits a presumption favoring state limitation periods in the adjudication of cases arising under federal law. The Rules of Decision Act states: "The laws of the several states, except where the Constitution or treaties of the United States or Acts of Congress otherwise require or provide, shall be regarded as the rules of decision in civil actions in the courts of the Uinted States, in cases where they apply."125 Althougl the legislative history of the Rules of Decision Act suggests that the Act was intended primarily to apply to diversity cases to ensure identical treatinent of state law in federal and state courts, ${ }^{126}$ the Act is not limited by its terms to diversity jurisdiction. The source of the right or cause of action is the critical question, not the basis for jurisdiction. ${ }^{127}$ The Erie doctrine establishes that under the Rules of Decision Act, state substantive law inust be applied in all actions arising under state law. ${ }^{128}$ It is less clear,

124. 28 U.S.C. $§ 1652$ (1982).

125. Id. The Act has three elements: (1) laws of the several states provide the rules of decision; but (2) only in cases where they apply; and (3) where the Constitution, treaties or statutes of the United States do not otherwise require or provide. For discussion of judicial interpretation of these elements see Note, Rules of Decision in Nondiversity Suits, 69 YALE L.J. 1428, 1432-33 (1960). See also Special Project, supra note 8, at 1026 n.79.

126. See Warren, New Light on the History of the Federal Judiciary Act of 1789, 37 HARv. L. REV. 49, 81-88 (1923).

127. See Hill, The Erie Doctrine in Bankruptcy, 66 HARv. L. REv. 1013, 1033-34 (1953); Merrill, The Common Law Powers of Federal Courts, 52 U. CHI. L. REv. 1, 28-29 (1985); Special Project, supra note 8, at 1026 n.79; see also Westen \& Lehman, Is There Life For Erie After the Death of Diversity?, 78 Mich. L. REv. 311, 367 \& n.166 (1980) (the Rules of Decision Act applies in nondiversity cases).

128. See Erie R.R. v. Tompkins, 304 U.S. 64 (1938); see also Guaranty Trust Co. v. York, 326 U.S. 99 (1945). 
however, what-if anything - the Act requires in actions arising under federal law. ${ }^{129}$ Some commentators have suggested that the Act creates at least a preference for state law based on federalist policies implied in the Act. Nevertheless, the Court lias not been persuaded by these arguments. ${ }^{130}$

As noted above, early cases such as Campbell v. Haverhill ${ }^{131}$ suggested that the Rules of Decision Act required apphication of state law absent specific contrary provisions of federal law, regardless of the source of the cause of action. General state statutes of limitations apphed of their own force, unless they discriminated against federal rights or clearly conflicted with federal policy. ${ }^{132}$ Justice Scalia recently resurrected this view in his concurrence in Agency Holding Corp. v. MalleyDuff \& Associates, ${ }^{133}$ noting further that federalism principles would support automatic adoption of state limitations periods even in the absence of the Rules of Decision Act. ${ }^{134}$

This interpretation views the area occupied by federal statutory law very narrowly. It posits that Congress enacts laws against the background of general state law, and any gaps are filled im by that background. Under this view, state law determines which limitations period is applicable. The only role for the federal courts is to determine whether federal policies preempt a particular state law. ${ }^{135}$ Accordingly, state limitations periods might govern a federal cause of action in forty-nine states, while in one state, where the relevant limitations period is too sliort, no valid statute of limitations would apply. ${ }^{136}$

The Scalia view has not been accepted by the Court, probably because it posits that states can limit enforcement of federal rights. The Supreme Court has long viewed issues incident to enforcement of federally created rights as matters of federal, not state, law. ${ }^{137} \mathrm{~A}$ limitations period is so closely associated with the scope of a federal substantive

129. See Mishkin, The Variousness of "Federal Law": Competence and Discretion in the Choice of National and State Rules For Decision, 105 U. PA. L. REv. 797, 802-04 (1957) (the Erie doctrine does not govern federal incorporation of state law).

130. DelCostello, 462 U.S. 151, 159 n.13 (1983) (rejecting the view that the Act constrains federal judicial lawmaking); see also Mishkin, supra note 129.

131. 155 U.S. $610,615-16$ (1895); see supra notes $23-26$ and accompanying text.

132. See supra notes $23-26$ and accompanying text.

133. 107 S. Ct. 2759 (1987).

134. Id. at 2770-72 (Scalia, J., concurring); see also Merrill, supra note 127, at 33-34.

135. See Campbell, 155 U.S. at 615; see also Merrill, supra note 127, at 34.

136. See Malley-Duff, 107 S. Ct. at 2768, 2770 (Scalia, J., concurring).

137. See, e.g., UAW v. Hoosier Cardinal Corp., 383 U.S. 696, 706 (1966) (characterization of federal action for purposes of selecting statute of limitations is a federal question); De Sylva v. Ballentine, 351 U.S. 570,580 (1956) ("The scope of a federal right is, of course, a federal question ...."); Board of County Comm'rs v. United States, 308 U.S. 343, 350-52 (1939). See also Mishkin, supra note 129, at 799 (the federal judiciary must have "competence . . . to declare the governing law" for "problems which bear substantial relation to an established federal operation"). 
right that it should properly be considered a matter of federal law. ${ }^{138}$

Other commentators have suggested that the Rules of Decision Act might influence selection of federal limitations periods in a second way. They argue that the Act expresses a congressional preference for state rules absent clear indication to the contrary. ${ }^{139}$ Thus, although state statutes of limitations do not govern federal statutes of their own force, the Rules of Decision Act creates a presumption in favor of state limitations, and is an independent constraint on federal common law powers. ${ }^{140}$

This second reading of the Rules of Decision Act is inconsistent with the generally accepted view that the Act is merely declarative of what would otherwise exist in its absence. ${ }^{141}$ If no independent content is to be ascribed to the Act, it cannot create a presumption regarding the substantive content of federal law, nor may it independently constrain federal common law powers. Thus the Act should not have any relevance to selecting rules of decision for federally created rights.

The inajority opinion in DelCostello v. International Brotherhood of Teamsters ${ }^{142}$ endorsed the view that the Act does not independently constrain federal judicial lawmaking. The Court explained that state limitations periods are borrowed "as a matter of interstitial fashioning of remedial details under the respective substantive federal statutes, and not because the Rules of Decision Act . . . requires it."143 The Act therefore does not bar courts from fashioning appropriate limitations periods based

138. See, e.g., Wilson v. Garcia, 471 U.S. 261, 269-71 (1985) (since characterization of a cause of action for limitations purposes is a question of federal law, federal courts are not bound by state court rulings on the matter); UAW v. Hoosier Cardinal Corp., 383 U.S. 696, 706 (1966). See generally Mishkin, supra note 129, at 802-10 (distinguishing federally incorporated state law from state law in Erie cases). The Supreme Court recently suggested that this result is mandated by the supremacy clause of the Constitution. See County of Oneida v. Oneida Indian Nation, 470 U.S. 226, 240 n.13 (1985) ("Under the Supremacy Clause, state-law time bars, e.g., adverse possession and laches, do not apply of their own force to Indian land title claims.").

139. See, e.g., Burbank, Interjurisdictional Preclusion, Full Faith and Credit and Federal Common Law: A General Approach, 71 CoRnell L. Rev. 733, 758-62 (1986); see also DelCostello v. International Bhd. of Teamsters, 462 U.S. 151, 172-73 (1983) (Stevens, J., dissenting) (courts borrow state statutes of limitations because Congress, through the Rules of Decision Act, directed them to do so).

140. See Burbank, supra note 139, at 762; cf. Merrill, supra note 127, at 28 ("[T] he Rules of Decision Act appears to be a severe restriction on lawmaking by federal courts."). But see Westen \& Lehman, supra note 127, at 369-70 (the Rules of Decision Act does not constrain the development of federal common law).

141. See Guaranty Trnst Co. v. York, 326 U.S. 99, 103-04 (1945); Hawkins v. Barney's Lessee, 30 U.S. (5 Pet.) 457, 464 (1831); Hill, supra note 127, at 1035; Mishkin, supra note 129, at 800 n.16; Westen \& Lehman, supra note 127, at 372.

142. 462 U.S. 151 (1983).

143. Id. at $159 \mathrm{n.13}$. See also id. at $174 \mathrm{n} .1$ (O'Connor, J., dissenting) (the Rules of Decision Act "only puts the question, for it simply requires application of state law unless federal law applies"). 
on their inherent authority to interpret and enforce congressional enactments.

\section{Interpretation of Congressional Silence}

While recognizing that the Rules of Decision Act does not require application of state limitations periods to federal statutory causes of action, the Supreme Court has nevertheless retained a presumption in favor of applying state law limitations. It has done so on the ground that Congress generally intends the courts to apply state law. The Court's underlying rationale is that Congress has acquiesced in - or endorsed the practice of-borrowing state law through its failure to enact either specific limitations periods for mdividual statutes, or a general, catch-all limitations period for civil actions. ${ }^{144}$

The interpretation of congressional silence as acquiescence to judicial action reflects a traditional understanding of the relationship between the judicial and legislative branches. The legislature enacts laws; the judiciary interprets them. If Congress disagrees with a judicial interpretation of an enactinent, Congress may overrule it. ${ }^{145}$ Consequently, if the legislature declines to overrule the judicial interpretation, its silence inay be taken as endorsement. ${ }^{146}$ This interpretation of congressional silence is often supported by evidence that Congress was aware of the issue in question, especially when the judicial ruling or practice is longstanding, ${ }^{147}$ or Congress has previously considered bills to overturn the rule. ${ }^{148}$

Nevertheless, there are good reasons to refrain from interpreting congressional silence as endorseinent. Congressional inaction can be attributed to inany factors. For example, it is generally acknowledged that it is much easier to kill a bill than to pass one. Congress may find the matter too trivial to deserve attention, or inay ignore it simply out of inertia. Congress inay, in fact, have no strong preference on the issue and thus will acquiesce to any judicial rule. Alternatively, meinbers of

144. See, e.g., Agency Holding Corp. v. Malley-Duff \& Assocs., 107 S. Ct. 2759, 2762 (1987); DelCostello v. International Bhd. of Teamsters, 462 U.S. 151, 158-59 \& n.12 (1983) (citing UAW v. Hoosier Cardinal Corp., 383 U.S. 696, 703-04 (1960)).

145. See, e.g., Westen \& Lehman, supra note 127, at 336-41 (1982).

146. See, e.g., UAW v. Hoosier Cardimal Corp., 383 U.S. 696, 704 (1966) ("[W] has disagreed with such an interpretation of its silence, it has spoken to overturn it by enacting a uniform period of limitations.").

147. See, e.g., Malley-Duff, 107 S. Ct. at 2771 (Scalia, J., concurring) ("[A]fter a century and a half of the Court's reacting to congressional silence by applying state statutes . . . by now at least it is reasonable to say that such a result is what Congress must expect, and hence intend, by its silence."); Hill, State Procedural Law in Federal Nondiversity Litigation, 69 HARV. L. REv. 66, 91-92 (1955) (courts should infer intent froin congressional silence in light of traditional practice).

148. See Malley-Duff, $107 \mathrm{~S}$. Ct. at 2772 (Scalia, J., concurring) (Congress' failure to pass bills limiting RICO actions supports inference of intent to apply state law). 
Congress may disagree with the judicial rule but find themselves unable to agree on a particular alternative. ${ }^{149}$ Moreover, the silent acquiescence of a subsequent Congress in the interpretation of a statute is not probative of the original, enacting Congress' intent. ${ }^{150}$

These general observations are particularly apt in the context of limitations periods. Limitations periods are hardly glamorous legislative issues, and are likely to seem in less urgent need of legislative attention than inany other problems. Since it is a fairly technical legal problem, Congress may well be content to delegate the responsibility for setting the rules to the judiciary.

In light of these interpretive problems, the absence of an express limitations period should not be constrned as an implicit instrnction tliat courts borrow state law limitations periods. All that may rationally be inferred is Congress' desire to furtlier the general policies behind the enacted legislation. Since accurate factinding is crucial to enforcement of a legislative schenne, judicial adoption of some form of time limit is consistent with this goal. Moreover, since repose is an important value in American law, ${ }^{151}$ it is generally unlikely that Congress would intend a cause of action to be without a time limitation. ${ }^{152}$

In soine instances, implications of congressional intent may be drawn from otlier legislation. For example, in Occidental Life Insurance Co. v. $E E O C{ }^{153}$ the Court reasoned that since Congress had set specific time limits for the initial stages of the employment practice grievance process, the absence of similar express time limits on actions initiated by the EEOC represented an affirmative intention to create an unliunted riglit of action. ${ }^{154}$ While such a negative inference may be persuasive when examining a single, coinpreliensive legislative scheme, it cannot be generalized; Congress' enactment of a specific statute of limitations to govern patents and antitrust actions, does not mean that Congress

149. See Grabow, Congressional Silence and the Search for Legislative Intent: A Venture Into "Speculative Unrealities", 64 B.U.L. REV. 737, 749-50 (1985); Note, A Limitation on Actions for Deprivation of Federal Rights, 68 CoLuM. L. REV. 763, 772-73 (1968).

150. Grabow, supra note 149 , at 747.

151. See, e.g., Adams v. Woods, 6 U.S. (2 Cranch) 336, 341 (1805).

152. The presumption that some form of limitation should apply may be rebutted by evidence of contrary congressional intent, however. For example, in County of Oneida v. Oneida Indian Nation, the Court found that the legislative history of an act granting state courts jurisdiction over Indian suits other than land claims indicated a congressional policy against application of state statutes of limitations to Indian land claims. 470 U.S. 226, $241 \&$ n. 14 (1985). Subsequent enactments limiting suits by the Umited States government on behalf of Indians were similarly held to rest on a congressional assumption that "the Indians' right to sue was not otherwise subject to any statute of limitations." Id. at 242. But cf. South Carolima v. Catawba Indian Tribe, Inc., 106 S. Ct. 2039 (1986) (applying state limitations period to Indian land claim due to the existence of an act expressly altering the relationship between the tribe and the federal government).

153. 432 U.S. 355 (1977).

154. Id. at $371-72$. 
intended to leave all other actions without time limitations. It would be unreasonable to infer that Congress intended a result so "utterly repugnant to the genius of our laws"15s unless it was clearly required for the implenientation of legislative policy.

Finally, the existence of express limitations periods in soine federal statutes should not be taken to imply that Congress intends state law to fill the gaps in all otlier federal statutes. Besides suffering front the problenis associated with interpreting congressional silence discussed earlier, this interpretation proves too inucli; if Congress assumed that state law would fill all gaps, then it need not have explicitly required courts to borrow state rules of decision in numerous other federal statutes. ${ }^{156}$ Indeed, by this logic, these statutes could be read to produce the opposite conclusion: that Congress ineant to imply adoption of federal common law where there is no express requirement that courts borrow state law.

Thus, it is clear that congressional silence is not necessarily indicative of an intent that courts look to state law to determine time limits. Indeed, the only fair inference may be that Congress wishes the courts to adopt some limitations period. Since hittle substance can be gleaned from congressional silence, federal courts are responsible for fashioning a common law rule that will effectuate the congressional policies behind federal statutes.

\section{B. Common Law Approaches}

Courts and commentators have argued that courts are ill-equipped to set a particular limitations period. ${ }^{157}$ Within broad boundaries, sucli a decision is largely arbitrary and therefore best left to legislative judgment. ${ }^{158}$ Because, for example, there is nothing imtrinsically proper about a thirty-six-1nonth limitations period as opposed to a thirty-sevenmontli period, courts cannot easily reason their way to the result. ${ }^{159}$

A limitations question also mvolves more precise line drawimg than courts like to perform. ${ }^{160}$ A court may feel uncoinfortable ruling that a

155. Adams v. Woods, 6 U.S. (2 Cranch) 336, 342 (1805).

156. See, e.g., Federal Tort Claims Act, 28 U.S.C. $\S \S 1346(b), 2674$ (1982).

157. See, e.g., Hemmings v. Barian, 822 F.2d 688, 689 (7th Cir. 1987) (Posner, J.) ("The length of a himitations period is arbitrary-you can't reason your way to it-and courts are supposed not to be arbitrary; when they are, they get criticized for it."); Mishkin, supra note 129, at 803-04 \& n.27 (noting "special difficulty in the judicial framing of a definite federal rule" for limitations periods).

158. See, e.g., Johnson v. Railway Express Agency, 421 U.S. 454, 463 (1975) ("any statute of limitations is necessarily arbitrary"); Note, Federal Statutes Without Limitations Provisions, 53 COLUM. L. REv. 68, 75 (1953) ("A limitaton [sic] period is an arbitrary measure traditionally and justifiably left to legislative determination...."). But see Note, supra note 1, at 771-73 (suggesting that the Supreme Court create a limitations period for civil rights actions under 42 U.S.C. $\S 1983$ ).

159. See Hemmings v. Barian, 822 F.2d 688, 689 (7th Cir. 1987).

160. See id. at 690 (courts are "not comfortable fixing arbitrary time periods, so ... they borrow 
claim filed two years after the relevant transaction or injury is timely, but one filed after two years and a day is too late, merely because of the passage of time. Unlike the related concept of laches, a limitations period does not allow the court discretion to consider the good or bad faith of the hitigants, the harm from delay, or the particular circumstances of a given case. ${ }^{161}$

The analogy process is a method of turning this quasi-legislative task into a task more suited to judicial reasonimg. ${ }^{162}$ It narrows the field of choice of appropriate himitations periods, and transforms the issue into a comparison rather than a bald assertion. In addition, the analogy process ideally elimmates much of the arbitrariness of the decision. ${ }^{163}$ The court extracts legislative policy judgments from analogous actions expressly governed by a statute of limitations and compares those judgments to the timeliness pohicies implicated by the case at bar. ${ }^{164}$

Other methods are possible. For example, the court might survey limitations periods for similar actions, both federal and state, and determine the appropriate time period without specifying a particular statute as the apphicable analog. ${ }^{165}$ For example, the court might choose the average limitations period. ${ }^{166}$ Alternatively the court might fashion a common law rule on the basis of its experience with the lifespan of evi-

a period fixed by a legislature"); Note, supra note 149, at 771 (setting limitations periods "leaves little room for the vagueness and flexibility that are the traditional virtues of rules made by judges").

161. See Holmberg v. Armbrecht, 327 U.S. 392, 396 (1946) (discussing laches); Hemmings, 822 F.2d at $689-90$.

162. See Johnson v. Railway Express Ageucy, 421 U.S. at 463-64; Hemmings, 822 F.2d at 690 ("[T]he court is choosing among arbitrary periods set by a legislature; but the choice itself is not arbitrary.").

163. But cf. Wilson v. Garcia, 471 U.S. 261,272 n.24 (1985) ("the adoption of one analogy rather than another will often be soinewhat arbitrary").

164. See supra text accompanying notes $35-42$.

165. In Sinith v. City of Chicago, 769 F.2d 408 (7th Cir. 1985) (Easterbrook, J.), the court determined that coinplaints alleging violation of the Shakman judicial decree (which controls the use of political patronage in Chicago municipal einployment) would be governed by a flxed limitations period rather than laches. The court surveyed federal and state limitations periods governing employment clains, including those under the Age Discrimination in Employment Act, 29 U.S.C. $\S$ 626(d) (1982); title VII of the Civil Rights Act of 1964, 42 U.S.C. $\S 2000 \mathrm{e}-5$ (e) (1982); National Labor Relations Act, 29 U.S.C. $\$ \S 158,160(b)$ (1982); federal civil service laws, 5 U.S.C. $\S 7118(\mathrm{a})(4)(\mathrm{A})(1982)$ and 5 C.F.R. $\S \S 1201.22(\mathrm{~b}), 1201.154(\mathrm{a})(1)$ (1987); Illinois Human Rights Act, Ill. ANN. STAT. ch. 68, para. 7-102(A)(1) (Smith-Hurd Supp. 1988); Public Labor Relations Act, ILL. ANN. STAT. ch. 48, para. 1611 (Smith-Hurd 1986); and state court decisions establishing limitations periods for claims under Chicago's civil service system. Smith, 769 F.2d at 412. Most of the statutes surveyed set limitations at 180 days. Although the court finally asserted that "[t]he Shakman decree is closely analogous to Title VII," and adopted title VII's limitations period, it did not explaim why the aualogy was superior to any of the other statutes discussed. Id. at 413 . Rather, the court seeined to develop an argument that the general consensus of federal and state legislatures was that most einploymeut practice clains should be filed withiu six months of accrual. See id. at 412-13.

166. Congress apparently used a similar approach in setting a limitations period for private antitrust claims. See S. REP. No. 619, 84th Cong., 1st Sess. 4-6, reprinted in 1955 U.S. CODE CoNG. 
dence, the difficulties of recognizing causes of action, and general policies concerning repose. ${ }^{167}$

Nevertheless, the analogy process is better suited to the task than the options discussed above. It requires less factfinding than the survey approach, and is more deferential to legislative judgments than a simple common law approach. When performed well, the analogy process takes into account the practical aspects of litigation, as well as the underlying purposes of the federal statute in question. Sucli considerations foster the adoption of limitations periods that accommodate the need for accurate factfinding and the defendant's interest in repose, while allowing tlie plaintiff sufficient time to vindicate legitimate rights.

This Comment proposes a modification of the current borrowing doctrime to take advantage of the best aspects of the analogy process. Part IV proposes that courts abandon the presumption favoring state law, and adopt a more functional approacli that focuses on practical timeliness concerns, witl respect to both the choice between federal and state law as the source of the limitations period, and the characterization of the cause of action for analogy purposes.

\section{IV}

\section{A Functional APPROACH to BORROWING Limitations PERIODS}

This Part recommends a inodification of the current borrowing doctrine, building upon the framework established in Agency Holding Corp. v. Malley-Duff \& Associates. ${ }^{168}$ In order to determine an appropriate limitations period for a federal statute, courts should follow the two-step inquiry outlined in Malley-Duff: (1) Should a single limitations period govern all claims under the statute? (2) Is state or federal law the proper source from which to select an analogous statute of limitations? ${ }^{169}$ Both inquiries should be performed with a sensitivity toward the ultimate goal: identifying the limitations period that best reflects the practicalities of litigating the claim, the need for repose, and the relative importance Congress likely attaches to prosecution of claims under the statute in question.

At each inquiry, the court slould examine all of the cliaracteristics

\& ADMIN. NEwS 2328, 2331-32 (surveying state limitations periods applied to antitrust claims and adopting the average period).

167. As Justice White noted, "Courts have not always been reluctant to 'create' statutes of limitations." UAW v. Hoosier Cardinal Corp., 383 U.S. 696, 713 (1966) (dissentimg opinion). Examples of common law time bars include the presumption of satisfaction on notes after the lapse of 20 years, the presumption of death after a seven-year absence, and the common law year-and-aday murder rule. See Special Project, supra note 8, at 1015 n.12.

168. 107 S. Ct. 2759 (1987).

169. Id. at 2762 . 
of the cause of action that have a bearing on timeliness matters. As noted previously, ${ }^{170}$ relevant factors include the types of behavior or harms addressed, the sophistication of potential hitigants, difficulties involved in discovering the injury and its source, procedural requirements, the types of evidence likely to be required, whether the litigants are enforcing public interests, and the need for rapid resolution of disputes. This Comment proposes that after considering these factors, the court should select a single uniforn characterization for a federal statute unless the statute is likely to give rise to claims that implicate vastly different timeliness interests.

In addition, this Comment proposes that courts abandon the presumption favoring state himitations. Instead, courts should examine whether limitations drawn from federal or from state law would best effectuate the federal pohicies underlying the statute. When Congress has enacted a limitations period that addresses functionally similar federal interests and timeliness concerns, that limitations period should apply. When there is no federal statute with strong functional similarity, a court may nevertheless adopt a federal limitations period if federal policies require uniformity. This Comment proposes a inethod of borrowing federal limitations periods in such circumstances based on examination of the factors described above. Finally, when federal interests favor adoption of state himitations periods, courts should employ the analogy method to borrow an appropriate state limitation.

\section{A. Uniform vs. Multiple Characterization}

The first step in selecting the appropriate limitations period is to decide whether all claims arising out of the federal statute should be characterized uniformly, or whether characterization should vary according to the facts and legal theories presented by each clain. ${ }^{171}$ In light of the need for predictability in limitations inatters, courts sliould generally prefer uniforin characterization of a statute. Nevertheless, multiple characterization is required whenever the statute in question is likely to give rise to claims that implicate vastly different timeliness interests. In making this determination, courts should consider whether Congress would hikely have accorded similar importance to all types of claims under the statute; it should also consider the need for speed in resolution of various disputes under the statute, the types of remedies available, and practical problems in hitigation. Such a functional approach will help courts characterize claims in a manner that will facilitate impleinentation of the federal statute.

170. See text accompanying notes 20-21, 38-42.

171. See Malley-Duff, 107 S. Ct. at 2762. 
If the statute in question routinely permits claims for both prospective relief and retrospective remedies, a single characterization may be inappropriate. For example, in Janzen v. Knox County Board of Education, ${ }^{172}$ the Sixth Circuit lield that uniform cliaracterization would be inappropriate in actions under the Education of All Handicapped Children Act. ${ }^{173}$ This statute permits actions to compel a scloool district to provide a proper special education program. Because the educational needs of a child should not remain undetermined for very long, a sliort limitations period is appropriate for sucli claims. ${ }^{174}$ However, in otleer claims under the statute, repose is less important, sucl as actions brought by parents for reimburseinent of expenses. ${ }^{175}$ Because urgency of claims under the statute varies, the application of different limitations periods is appropriate.

Similarly, a uniform limitations period would be inappropriate for all claims arismg under the Labor Management Relations Act (LMRA) ${ }^{176}$ because vastly different timeliness concerns are involved in the various causes of action available under the Act. For example, the interest in rapid resolution of disputes is much greater when the conflict involves day-to-day labor-manageinent relations than in a dispute over pension funding. ${ }^{177}$ Similarly, suits for dainages to compensate for secondary boycott activities prohibited by section 303 of the LMRA ${ }^{178}$ should not be governed by the same limitations period applicable to "hybrid" suits under DelCostello. While the federal interest in promoting private settlement of labor disputes througl established grievance procedures suggests that a sliort limitations period is appropriate to "hybrid" suits, the short limitations period nay be inappropriate when, as in most secondary boycott actions, the litigants have no contractual relationship and therefore no access to such grievance procedures. ${ }^{179}$

This functional approach differs from the approach taken by the Supreme Court in Wilson v. Garcia ${ }^{180}$ and Agency Holding Corp. v. Malley-Duff \& Associates. ${ }^{181}$ In each of these cases, the Court justified selec-

172. 790 F.2d 484 (6th Cir. 1986).

173. 20 U.S.C. $\S \S 1401-1461$ (1982) (amended 1983, 1986). See Janzen, 790 F.2d at 487.

174. 790 F.2d at 487.

175. Id. at $487-88$.

176. 29 U.S.C. $\S \S 141-197$ (1982).

177. See Adams v. Gould, Inc., 739 F.2d 858, 867 (3d Cir. 1984), cert. denied, 469 U.S. 1122 (1985).

178. 29 U.S.C. § 187 (1982).

179. See, e.g., Monarch Long Beach Corp. v. Soft Drink Workers, Local 812, 762 F.2d 228, 231 (2d Cir.) (emphasizing that "[l]abor peace will not be disrupted if ... suits are not rapidly resolved" in secondary boycotts), cert. denied, 474 U.S. 1020 (1985). For analysis reaching the conclusion that all LMRA claims should be governed by a uniform limitations period, see Comment, supra note 89.

180. 471 U.S. 261 (1985).

181. 107 S. Ct. 2759 (1987). 
tion of a uniform characterization of claims under the statute in question solely on the grounds of avoiding "intolerable 'uncertainty and time-consuming litigation." "182 Although establishment of clear rules is a valid concern, it is not the only concern. The Court should have considered other factors relevant to characterizing a statute for limitations purposes.

Nevertheless, a functional analysis in both these cases may have led to the saine result. Both section 1983 and RICO were designed to provide retrospective relief-remedies for past injuries. The federal interest in redressing civil rights violations under section 1983 is likely to be essentially the same regardless of the specific circumstances in which they arose. In RICO, the provision for treble damages to compensate for injury resulting froin patterns of racketeering activity suggests that Congress gave considerable weight to prosecution of all RICO claims regardless of the underlying facts. Absent a showing that certain types of clains implicate vastly different timeliness concerns, uniforin characterization is appropriate for both statutes to further the goal of predictability in limitations matters.

\section{B. Federal vs. State Limitations Periods}

The second step in setting a limitations period is to choose between federal and state law as the source of potentially analogous statutes of limitations. ${ }^{183}$ As discussed above, no doctrine mandates a presumption in favor of state law. In fact, the relevant concerns may favor a federal limitations period. The ultimate question is what linitations period Congress would have preferred had it considered the issue. An enacted federal statute of limitations einbodies a congressional policy judgment, as opposed to a state statute of limitations, which represents the judginent of a state legislature. Moreover, only federal statutes of limitations can provide national uniformity in the enforcement of federal rights, and reflect the weight of uinquely federal interests in the balance.

This Coinment proposes a four-step inquiry to deterinine the proper source of law: (1) Does a federal statute of limitations disclose Congress' balance of the particular concerns inplicated by the unlimited statute? (2) Do federal interests favor the "generahization" of a federal statute of limitations? (3) Do federal interests favor integration with state law? and (4) Should state law be adopted by default?

Most federal statutes of limitations were enacted for specific causes of action, while many state statutes of limitations were intended to cover general categories of actions. Courts may therefore hesitate to apply such specific federal statutes of limitations to claims for which they were

182. Id. at 2764 (quoting Wilson, 471 U.S. at 272).

183. Id. at 2762. 
not enacted. Nevertheless, as the DelCostello Court noted, ${ }^{184}$ whenever a court borrows a statute of limitations-whether from federal or state law-it applies a limitations period in a way not contemplated by the legislature that enacted the limitations statute. Therefore, the borrowing process should be essentially the same regardless of the source of the borrowed limitations. The court should compare evidentiary concerns, the practicalities of hitigation, the types of mjury redressed, and the remedies provided by the cause of action.

Sometimes this inquiry will disclose a particular federal statute of limitations that provides a close analogy to the action at bar. This is most likely to occur when the potential federal analog addresses conduct similar to that addressed by the unlimited statute. In sucl cases, the court should adopt the relevant federal limitations period because this period approximates the balance between interests im repose and prosecution that Congress would have reached liad it considered the issue.

In other cases, no exact matcli will be available. Nevertlieless, a court might find that the pohicies behind a federal statute would best be served by a uniform federal hinitation. In such cases, the court sliould be free to adopt a uniform federal limitations period, based on a somewliat rougher analogy, in order to implement the federal statutory sclieme effectively. ${ }^{185}$

On the otler hand, state limitations periods should be borrowed when the federal statutory sclieine is best integrated witl local laws. This situation inay arise eitler because Congress has expressly directed courts to use state law to fill gaps in the federal scheme, ${ }^{186}$ or because the federal statute involves interests that are traditionally local in nature. State limitations periods also may be adopted by default when no appropriate federal limitations period can be found.

Unlike the DelCostello/Malley-Duff approach, this proposal does not involve a coinparison of potentially analogous federal and state statutes. If the court chooses a federal limitations period, it does so without regard to what state statutes are available in the case at bar. As a result, the happenstance of the place of suit will not influence the choice between federal and state rules. ${ }^{187}$

The following sections will discuss each of the four steps of the proposed inquiry in turn, giving examples of how they miglit be applied to various federal statutory actions.

184. See DelCostello v. International Bhd. of Teamsters, 462 U.S. 151, 169 n.21 (1983).

185. See, e.g., Malley-Duff, 107 S. Ct. 2759. See also infra notes 198-214 and accompanying text.

186. See, e.g., Federal Torts Claims Act, 28 U.S.C. $\$ \S 1346(b), 2674$ (1982).

187. See supra text accompanying notes 110-113. 


\section{Closely Fitting Federal Analogs}

The court should first determine whether an existing statute of limitations represents Congress' balance of the particular timeliness interests implicated by the statute in question. A federal statute of limitations that governs a cause of action arising from similar conduct often will provide sucl a close analogy. The evidentiary requirements and the sophistication of the litigants are likely to be similar to those involved under the statute in question. In addition, potential defendants will lave similar interests in repose.

One candidate for a closely fitting borrowed federal limitations period is the implied right of action in securities law under SEC Rule 10b-5. ${ }^{188}$ As many commentators have recognized, ${ }^{189}$ the express linnitations periods applicable to private actions under the federal securities laws ${ }^{190}$ represent Congress' balance of the relevant timeliness interests. Because there is substantial overlap between the conduct addressed by the express and implied actions, ${ }^{191}$ the harms addressed (private economic injury) and the federal interest in permitting private claims (policing information in securities inarkets) are substantially sinnilar. Disputants are also likely to be similarly situated. The remedies available are also similar (nnoney damages), which suggests that a defendant's interest in repose is likely to be the same for botl express and inplied actions. Moreover, proof of the violations is likely to rely upon sinilar types of docuinentary and testimonial evidence.

The similarities between these causes of action should be sufficient for the adoption of a federal linitations period; the question of what period Congress would likely have preferred has already been answered by Congress. From a practical standpoint, a uniform period would sinn-

188. 17 C.F.R. § 240.10b-5 (1987).

189. See, e.g., L. LOSS, FUNDAMENTALS OF SECURITIES REGULATION 995 (1988); Ruder, Civil Liability Under 10b-5: Judicial Revision of Legislative Intent?, 57 Nw. U.L. REV. 627, 680-81 (1963); Schulman, Statutes of Limitation in 10b-5 Actions: Complications Added to Confusion, 13 WAYNE L. REv. 635, 637 (1967); Report of the Task Force on Statute of Limitations For Implied Actions, 41 Bus. LAw. 645, 646-47 (1986) [hereinafter Report]; Note, Limitation Borrowing in Federal Courts, 77 Мich. L. Rev. 1127, $1133-34$ \& n.42 (1979); Note, A Cry For Help: The Ninth Circuit and the Statute of Limitations in Rule 10b-5 Actions, 22 UCLA L. Rev. 947, 950-51 (1975). See also ALI MODEL FED. SEC. CODE $\S 1727$ (f) (1980) (instructing courts to borrow analogous limitation provisions for judicially imphed causes of action).

The Third Circuit recently applied the linitations period for express causes of action under the Securities Exchange Act of 1934 to implied section 10(b) clains. See In re Data Access Systems Securities Litigation, 843 F.2d 1537 (3d Cir.), cert. denied, 109 S. Ct. 131 (1988).

190. See Securities Act of 1933 § 13, 15 U.S.C. $\$ 77 \mathrm{~m}$ (1982); Securities Exchange Act of 1934 $\S \S 9(\mathrm{e}), 18(\mathrm{c}), 29(\mathrm{~b}), 15$ U.S.C. $\S \S 78 \mathrm{i}(\mathrm{e}), 78 \mathrm{r}(\mathrm{c}), 78 \mathrm{cc}(\mathrm{b})(1982)$.

191. See Herman \& MacLean v. Huddleston, 459 U.S. 375, $383-84$ (1983) (permitting 10b-5 remedy for conduct addressed by express securities reinedies). 
plify the complex body of law on limitations of $10 \mathrm{~b}-5$ actions, ${ }^{192}$ thereby promoting the federal interest in providing clearer notice to potential plaintiffs and defendants as to their respective rights and habilities. Moreover, it serves interests in fairness by removing disparities in the prosecution of identical claims. ${ }^{193}$

Unseaworthiness claims and the limitations period in the Jones Act $^{194}$ provide another good example of a close fit between an unlimited federal remedy and a federal limitations period. The limitations period in the Jones Act represents Congress' balance of the concerns relevant to claims of injured ship employees. The Jones Act governs conduct similar to that governed by unseaworthiness claims: shipowners' management of their ships. Both actions allow ship employees to recover damages for bodily injuries suffered in employment, and imphicate shipowners' interests in being free from such pecuniary liability. Even thougli the elements of the causes of action and defenses differ somewhat, ${ }^{195}$ similar facts would have to be proved regarding the cause and extent of the injury, the conduct of officers and crew, and the condition of the ship. Thus, evidentiary concerns are similar in the two actions. The Jones Act three-year limitations period would therefore provide an appropriate analogous limitations period for unseaworthiness claims, regardless of whether state law provides a shorter or longer period of limitation. ${ }^{196}$

This issue is now moot, however, since in 1980 Congress enacted a three-year limitations period for "suit[s] for recovery of damages for personal injury or death, or both, arising out of a maritime tort." 197 Nevertheless, it is worth noting that a functional apphication of the analogy process would have resulted in adoption of a three-year limitations period through federal common law. This suggests that there is some validity in attempting to estimate Congress' balance of the relevant timehiness interests through the analogy process.

\section{Generalizing Federal Models}

In soine cases a federal limitations period is the best analog for purposes of uniformity, even in the absence of a federal limitations period that addresses similar behavior. For example, RICO may require a urnform federal limitations period, despite tlie apparent lack of a close fed-

192. See, e.g., L. Loss, supra note 189 , at $992-94$ (describing the complexity of the current approach); Report, supra note 189, at 648-54 (surveying the decisional law in this area).

193. See Report, supra note 189 , at 648-54.

194. 46 U.S.C. $\S 688($ a) (1982); see supra note 51.

195. See McAllister v. Magnohia Petroleum Co., 357 U.S. 221, 224 (1958).

196. $C f$. id. at 229 (Brennan, J., concurring) (suggestimg this result).

197. Pub. L. No. 96-382, § 1, 94 Stat. 1525 (1980) (codified at 46 U.S.C. $\$ 763 a$ (1982)). See Cooper v. Diamond M Co., 799 F.2d 177 (Sth Cir. 1986) (applying section 763a to unseaworthiness claim), cert. denied, 107 S. Ct. 2177 (1987). 
eral analog. As the Malley-Duff Court explained, RICO litigation "commonly involve[s] interstate transactions." 198 If state limitations periods apphied, a single transaction giving rise to RICO claims might be governed by more than one limitations period. ${ }^{199}$

The Clayton Act serves very different purposes than RICO. The former attempts to promote economic coinpetition, ${ }^{200}$ while the latter addresses organized crime and corruption. ${ }^{201}$ Nevertheless, the MalleyDuff Court correctly applied the Clayton Act's limitations period to RICO claims. One indicator of the significance Congress attaches to civil claims under federal statutes is the type of remedies it provides in the statutory framework. Both RICO and the Clayton Act permit treble damage awards. This suggests that Congress attaclied great significance to prosecution of private claims, and that the federal interests extend beyond the redress of private mjuries. It also suggests that potential RICO defendants liave interests in repose similar to those of potential antitrust defendants. In addition, both statutes address sinilar types of injury: economic injury. ${ }^{202}$ Therefore, proof of a RICO injury inay rely on the same general types of evidence as those used in antitrust cases. Under the proposed "generalizing" approach, the Clayton Act limitations period becomes a model limitations period for actions for economic mjury that Congress deems imiportant enougli to provide treble dainages.

Similarly, the federal statute of limitations for civil penalties and forfeitures ${ }^{203}$ may provide a good general model for limitations of actions $\mathrm{m}$ which the private plaintiffs-acting as private attorneys general-vindicate public as well as private interests, such as civil rights actions. Section 2462 of title 28 provides in relevant part: "Except as otherwise provided by Act of Congress, an action, suit or proceeding for the enforcement of any civil fine, penalty, or forfeiture, pecuniary or otlierwise, slrall not be entertained unless commenced within five years . . .."204 Courts have consistently interpreted this statute narrowly, applying it "only to actions on belralf of the United States and qui tam actions"20s to enforce sanctions imposed for violation of federal

198. Agency Holding Corp. v. Malley-Duff \& Assocs., 107 S. Ct. 2759, 2766 (1987).

199. Id. (noting that "conceivably the statute of limitations of several States could govern any given RICO claim").

200. See L. Sullivan, Handbook of the Law of ANTitrust 20 \& nn.1-3 (1977).

201. See Malley-Duff, 107 S. Ct. at 2765.

202. See id. at 2764.

203. 28 U.S.C. $\$ 2462$ (1982).

204. Id.

205. Bertha Bldg. Corp. v. National Theatres Corp., 269 F.2d 785, 788-89 (2d Cir. 1959), cert. denied, 361 U.S. 960 (1960). See also Meeker v. Lehigh Valley R.R., 236 U.S. 412, 423 (1915) (section 2462's predecessor not applicable to action for damages); Payne v. A.O. Smith Corp., 578 F. Supp. 733, 736 n.3 (S.D. Ohio 1983) (section 2462 does not govern suit for private damages under the Consumer Product Safety Act). 
law. ${ }^{206}$ Such actions are meant to benefit the public at large, rather than to compensate individuals for private loss. Similarly, suits brought by private attorneys general benefit the public at large as well as the individual litigant. Because section 2462 reflects the congressional balance of interests in repose and prosecution of civil claims that benefit the public at large, ${ }^{207}$ it may serve as a good inodel for private attorney general actions, where federal interests favor a uniform period. ${ }^{208}$

Similar reasoning would suggest that section 2462 would therefore provide an appropriate uniform limitations period for civil rights actions under section 1983. ${ }^{209}$ Civil rights plaintiffs serve public interests as well as private; by seeking to enforce the provisions of the Constitution, they protect the public at large froin governmental overreaching. ${ }^{210}$ Moreover, there is a strong federal interest in uniform protection of federal constitutional rights because they are basic to citizenship. ${ }^{211}$

Some statutes of limitations would not serve well as general models, however. For example, an unusually sliort limitations period should not be borrowed for other statutory actions unless the underlying interests and behavior addressed match very closely, because it is unlikely that Congress would want to create a severely limited right of action without explicitly stating the applicable limits. ${ }^{212}$ Thus, the six-1nonth limitations period for filing unfair labor practice claims witl the NLRB $^{213}$ should not be generalized to cover all labor-related actions because the short period suggests a very precise balance struck by Congress. ${ }^{214}$

Because this generalizing approacl to borrowing federal limitations

206. See Note, supra note 39, at 206. "A qui tam action is brought by an informer under a statute which establishes a penalty for its violation. The informer recovers a share of the penalty; the remainder goes to the government." Id. at 206 n.79.

207. Compare 18 U.S.C. $\$ 3282$ (1982), which similarly sets a residual five-year limitations period for noncapital criminal prosecutions.

208. For an argument favoring application of section 2462 to citizen suits under the Clean Water Act, see Note, supra note 39.

209. 42 U.S.C. $\$ 1983$ (1982).

210. See, e.g., S. REP. No. 1011, 94th Cong., 2d Sess. 2-3, reprinted in 1976 U.S. CoDE CONG. \& ADMIN. NEwS 5908, 5909-10 (noting that private civil rights plaintiffs play the role of private attorneys general in enforcing federal civil rights laws).

211. But see Wilson v. Garcia, 471 U.S. 261, 275 (1985) ("the need for national uniformity "has not been held to warrant the displacement of state statutes of limitations for civil rights actions" ") (quoting Board of Regents v. Tomanio, 446 U.S. 478, 489 (1980)).

212. The Supreme Court has suggested that courts should be cautious about borrowing limitations periods of an unusual length. See UAW v. Hoosier Cardinal Corp., 383 U.S. 696, 707 n.9 (1966).

213. 29 U.S.C. $\$ 160(b)$ (1982).

214. A six-month limitations period is not unusual for adininistrative remedies, however. See Smith v. City of Chicago, 769 F.2d 408 (7th Cir. 1985) and discussion supra note 165. Therefore, section 10(b) might be an appropriate "general" inodel limitations period for filing claims with admimistrative agencies. Nevertheless, the difference in burdens imposed on plaintiffs filing claims in court and those filing claims with agencies suggests that limitations on administrative actions should not be generalized to cover court actions. See Burnett v. Grattan, 468 U.S. 42 (1984). 
periods draws analogies between causes of action that address different underlying conduct, courts should be somewhat cautious in adopting it. Nevertheless, when the federal interests implicated by a statutory claim suggest that a uniform federal rule is appropriate, this model offers a useful method of identifying the proper balance of interests in crafting a statute of limitations.

\section{Integration With State Law}

Limitations periods should be drawn from state law whenever Congress has exphicitly required this as part of the federal scheme. Thus, for example, state limitations periods apply to claims under the Federal Torts Claims Act, which contains express congressional instructions to implement the remedies in accordance with state law. ${ }^{215}$

Usually, however, the federal statute will not contain such express instructions and other factors must be examined. For example, if the statute implicates traditionally local interests or delegates considerable responsibility for implementation to the states, the local limitations period should be adopted. The Education of All Handicapped Children Act (EAHCA) ${ }^{216}$ illustrates this point well. The EAHCA addresses educational programs, an area traditionally under local control. The statute delegates much of the responsibility for impleinenting programs to state agencies. ${ }^{217}$ Private reinedies under the Act therefore may best be implemented in conjunction with other remedies available through state agencies. In addition, injuries addressed under the Act generally are localized; no interstate transactions and their corresponding complexities are likely to be involved. Thus, national uniformity is less inportant in EAHCA actions than actions brought pursuant to RICO. Adoption of state law time bars therefore would be appropriate.

\section{State Law By Default}

State law may also be chosen by default. In hight of the traditional reliance on state law analogs, a court may turn to state law when no close federal analog is available, and when the federal interests in uniformity are not strong enough to justify generalizing an imperfectly fitting federal analog.

For example, state limitations periods would properly be borrowed for actions under the Alien Tort Statute. ${ }^{218}$ The Alien Tort Statute creates a federal right of action for torts committed in violation of interna-

215. 28 U.S.C. $\$ \$ 1346(b), 2674$ (1982).

216. 20 U.S.C. $\$ \S 1401-1461$ (1982).

217. See, e.g., 20 U.S.C. $\$ 1413$ (1982) (requiring state educational agencies to submit plans for implementation of the federal program).

218. 28 U.S.C. $\S 1350$ (1982). The Alien Tort Statute provides, in relevant part, that district 
tional law. ${ }^{219}$ No express federal statute of limitations addresses similar conduct, or represents Congress' balance of the relevant timeliness concerns. ${ }^{220}$ Although national uniformity might be preferable for the sake of simplicity, the wrongs redressed are primarily personal and probably would not routinely involve interstate transactions. Thus, federal interests do not favor borrowing a inore distant federal analog.

On the other hand, the Alien Tort Statute does not contain any express direction froin Congress to borrow state law. Moreover, since the actions redress wrongs that occur outside the country, there is no compelling need to integrate sucli actions with state law reinedies. Nevertheless, because federal statutory law does not provide a suitable source for a limitations period, courts may turn to state law by default. Courts confronting claims under this statute therefore should apply the forum state's limitations period for personal injury. ${ }^{221}$

\section{CONCLUSION}

Althougli the analogy inethod of setting limitations for federal statutory rights has some shortcomings, it is a reasonable method of turning a largely arbitrary, quasi-legislative task into a task more amenable to judicial reasoning. To employ the analogy method successfully, however, courts must reineinber the purpose of drawing analogies: to inake use of a legislature's judgment about the relative values of prosecution and repose in similar circumstances. The analytic framework outlined above focuses the court's attention on the factors relevant to the selection of a proper limitations period.

Because neither the Rules of Decision Act nor implied congressional intent creates a presumption in favor of state limitations periods, courts have the responsibility to adopt a limitations period that best serves the purposes of the federal statute at issue. The framework proposed in this Cominent encourages courts to examine the legal context in which the federal remedy operates and to determine whether an express limitations period addresses functionally similar federal interests, whether national uniformity is needed to implement the reinedy, or whether the reinedy is best integrated with state law. By examining the practicalities of hitigatmg federal claims and by giving full weight to relevant federal interests,

courts shall have "original jurisdiction of any civil action by an alien for a tort only, committed in violation of the law of nations or a treaty of the United States." Id.

219. See Filartiga v. Pena-Irala, 630 F.2d 876, 887 (2d Cir. 1980); Tel-Oren v. Libyan Arab Republic, 726 F.2d 774, 777 (D.C. Cir. 1984) (Edwards, J., concurring), cert. denied, 470 U.S. 1003 (1985). But see id. at 798-823 (Bork, J., concurring) (section 1350 constitutes merely a grant of jurisdiction, and does not create a cause of action).

220. See Forti v. Suarez-Mason, 672 F. Supp. 1531, 1547-48 (N.D. Cal. 1987).

221. Cf. id. at $1547-49$ (applying California limitations period for personal injury actions, after drawing analogy to federal civil rights claims under 42 U.S.C. $\S 1983$ ). 
courts can transform the analogy process froin a relatively abstract intellectual exercise into a more primcipled and predictable method of inplementing federal statutes to best effectuate congressional intent. 